\title{
11. CALCAREOUS NANNOFOSSILS FROM THE SOUTHEAST GREENLAND MARGIN: BIOSTRATIGRAPHY AND PALEOCEANOGRAPHY
}

\author{
Wuchang $\mathrm{Wei}^{2}$
}

\begin{abstract}
The distribution of calcareous nannofossils in Leg 152 sites on the southeast Greenland Margin is documented. The nannofossil biostratigraphy established here provides valuable age information for the recovered sediments and a number of important events, including the initiation of marine sedimentation in the Irminger Basin in the early Eocene (52-53 Ma), the onset of North Atlantic Deep Water around 11.5 Ma, and the earliest occurrence of dropstones in the Irminger Basin at about $7 \mathrm{Ma}$ or older. Nannofossil assemblages indicate significant warmth in the high latitudes during the Eocene and progressive deterioration of the climate since the late Eocene. The last consistent occurrence of warm-water taxa at about $12 \mathrm{Ma}$ in the Irminger Basin may suggest the onset of the cold East Greenland Current at this time. Reworked Cretaceous nannofossils in Pleistocene sediments may be the result of extensive discharge of icebergs from the North Sea-Denmark area beginning in the middle Pleistocene.
\end{abstract}

\section{INTRODUCTION}

Ocean Drilling Program Leg 152 drilled six sites on the southeast Greenland Margin, along a transect from the shelf to Irminger Basin (Fig. 1). The abundance of calcareous nannofossils in the recovered sediments varies considerably, but it generally decreases shoreward and uphole. Species diversity is lower than those at lower latitudes, and nannofossil biostratigraphic resolution is lower due to the scarcity or absence of many standard zonal markers. Nevertheless, calcareous nannofossils still provide the primary means of dating the recovered sediments. This chapter provides a detailed documentation of the stratigraphic distribution of the nannofossils and discusses their biostratigraphy. In addition, some brief remarks on paleoclimate and paleoceanography are made based on the semiquantitative nannofossil data.

\section{METHODS}

Samples for this study were taken aboard ship at a frequency of one sample per core section. Smear slides were made directly from unprocessed samples and examined with a light microscope at a magnification of $1000 \times$. The abundance of calcareous nannofossils on each slide was estimated and recorded in the following semi-quantitative categories (each successive category is about 5 times the preceding category):

$\mathrm{R}($ rare $)=1$ specimen in $31-150$ fields of view

$\mathrm{F}(\mathrm{few})=1$ specimen in $6-30$ fields of view

$\mathrm{C}($ common $)=1$ specimen in $1-5$ fields of view

A (abundant $)=2-10$ specimens per field of view

$\mathrm{V}($ very abundant $)=>10$ specimens per field of view

The abundance of reworked specimens was recorded in lowercase letter. For the preservation of nannofossil assemblages: $\mathrm{G}=$ good, little evidence of etching or overgrowth; $\mathrm{M}=$ moderate, etching or overgrowth is apparent; and $\mathrm{P}=$ poor, there is significant etching or overgrowth and identification of some species is impaired.

${ }^{1}$ Saunders, A.D., Larsen, H.C., and Wise, S.W., Jr. (Eds.), 1998. Proc. ODP, Sci. Results, 152: College Station, TX (Ocean Drilling Program).

${ }^{2}$ Scripps Institution of Oceanography, University of California, San Diego, La Jolla, CA 92093-0215, U.S.A.wwei@ucsd.edu
Previous studies of nannofossils from drill sites in the northern high latitudes include Müller (1976), Steinmetz (1978), Donnally (1989), Firth (1989), and Knüttel et al. (1989). However, no Cenozoic calcareous nannofossil zonation for the northern high latitudes has yet been established. Nannofossil zones recognized in this study are given in the widely used zonation of Okada and Bukry (1980). The emphasis, however, has been on individual datums, including a number of datums that were not used in the original zonation but have since been documented in recent studies (Gartner, 1992; Wei and Wise, 1992; Young et al., 1994) and are useful for Leg 152 sediments. For convenience, the numerical ages of the datums used in this chapter are still in reference to the geomagnetic polarity time scale of Cande and Kent (1992), as presented graphically in Larsen, Saunders, Clift, et al. (1994). Some revisions of this geomagnetic polarity time scale have recently been made (Cande and Kent, 1995; Wei, 1995), but they do not significantly affect the ages discussed in this chapter.

Bibliographic references for the calcareous nannofossil species used in this study can be found in Perch-Nielsen (1985). Most species encountered and some critical occurrences of marker species are documented in Plates 1-3. A summary of nannofossil biostratigraphy of Leg 152 sites is presented in Table 1.

\section{NANNOFOSSIL BIOSTRATIGRAPHY Site 914}

Core recovery for the glaciomarine sediments at this site was generally very poor, and no suitable sediments were available for nannofossil analysis for much of Hole 914B (see Table 2). Calcareous nannofossils are generally rare or absent in the Pleistocene sediments and common in the lower Oligocene sediments.

Samples 152-914A-1H-1, $66 \mathrm{~cm}$, and 1H-2, $66 \mathrm{~cm}$, contain both Emiliania huxleyi and Coccolithus pelagicus and are most likely Holocene in age based on the Pleistocene nannofossil biochronology established for the subarctic North Atlantic by Gard and Backman (1990). The interval from Sample 152-914A-1H-CC through Sample 152-914A-2H-4, $66 \mathrm{~cm}$, is barren of calcareous nannofossils, and probably represents the last glacial interval (oxygen isotope Stages 2-4) when the cold climate excluded the calcareous nannoplankton from the area. Samples 152-914A-2H-5, $66 \mathrm{~cm}$, through 3H-CC contain rare specimens of E. huxley, and may be correlated with oxygen isotope stage 5 or, at the earliest, oxygen isotope stage 8 according to 


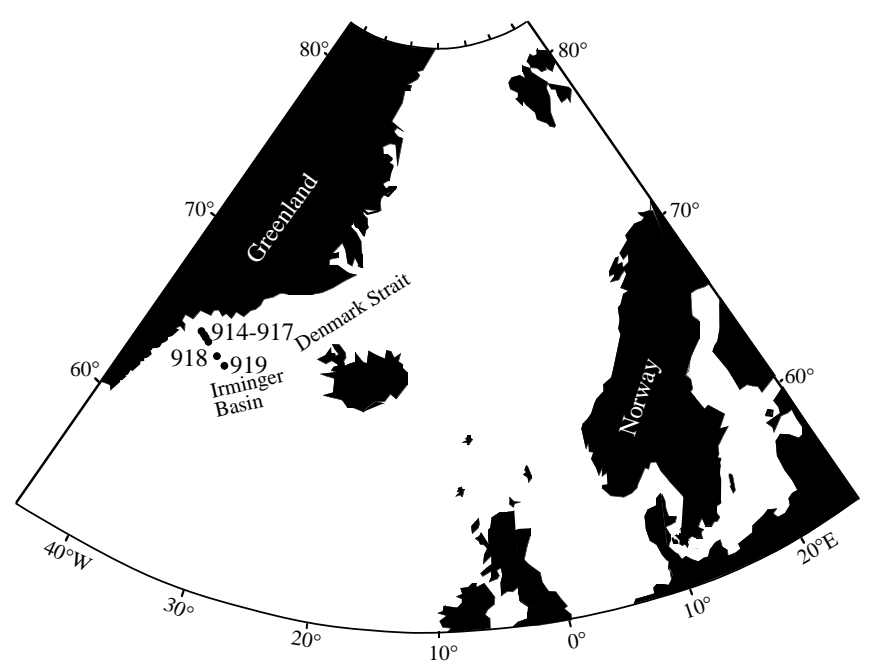

Figure 1. Location map of Leg 152 drill sites. the chronology of Gard and Backman (1990). Sample 152-914B-8R$\mathrm{CC}$ contains a mixture of nannofossils of different ages, including Cretaceous, Paleogene, and Pleistocene species (Table 2). Apparently, these have been reworked in this glaciomarine sediment. The youngest species found in this sample is Gephyrocapsa sp. (>4.0 $\mu \mathrm{m})$, which indicates that the sediment is still Pleistocene in age.

Common and relatively diverse Paleogene nannofossil assemblages were found in Samples 152-914B-15R-CC through 17R-CC. Based on the presence of Chiasmolithus altus, Reticulofenestra daviesii and $R$. umbilicus in the absence of Isthmolithus recurvus, Samples 152-914B-15R-CC and 16R-2, $31 \mathrm{~cm}$, can be placed near the top of CP16, close to $32 \mathrm{Ma}$. Samples 152-914B-16R-CC and $17 \mathrm{R}-\mathrm{CC}$ contain all the above species in addition to Isthmolithus recurvus, whereas $R$. reticulata is absent. These assemblages suggest an early Oligocene age.

\section{Site 915}

One hole was drilled at this site and core recovery was very poor or zero for the upper 17 cores. Sample 152-915A-1R-CC is barren of calcareous nannofossils (Table 3 ). The next sedimentary sample suitable for nannofossil analysis is Sample 152-915A-11R-CC. The in-

Table 1. Summary of nannofossil biostratigraphy of Leg 152 sites.

\begin{tabular}{|c|c|c|c|c|c|c|}
\hline Age & Zones & Site 914 & Site 915 & Site 917 & Site 918 & Site 919 \\
\hline \multirow{3}{*}{$\frac{\vec{m}}{\frac{\vec{m}}{\alpha}}$} & $\mathrm{CN} 15$ & A: $1 \mathrm{R}-1 / 3 \mathrm{R}-\mathrm{CC}$ & & & A: $1 \mathrm{H}-1 / 4 \mathrm{H}-1$ & A: $1 \mathrm{H}-1 / 4 \mathrm{H}-5$ \\
\hline & $\mathrm{CN} 14$ & \multirow{2}{*}{ B: $8 \mathrm{R}-\mathrm{CC}$} & & & \multirow{2}{*}{ A: $4 \mathrm{H}-3 / 24 \mathrm{X}-\mathrm{CC}$} & $\mathrm{A}: 4 \mathrm{H}-\mathrm{CC} / 7 \mathrm{H}-3$ \\
\hline & CN13 & & & & & $\begin{array}{l}\text { A: } 7 \mathrm{H}-5 / 10 \mathrm{H}-\mathrm{CC} \\
\text { B: } 3 \mathrm{H}-1 / 8 \mathrm{H}-\mathrm{CC}\end{array}$ \\
\hline \multirow{3}{*}{ 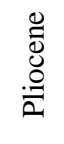 } & $\mathrm{CN} 12$ & & & & A: $25 \mathrm{X}-\mathrm{CC} / 31 \mathrm{X}-\mathrm{CC}$ & \\
\hline & $\mathrm{CN} 11$ & & & & \multirow{2}{*}{ D: $14 \mathrm{R}-1 / 24 \mathrm{R}-2$} & \\
\hline & $\mathrm{CN} 10$ & & & & & \\
\hline \multirow{9}{*}{ 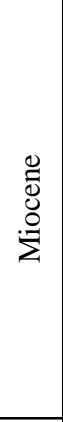 } & CN9 & & & & \multirow{3}{*}{ D: $24 \mathrm{R}-3 / 37 \mathrm{R}-3$} & \\
\hline & CN8 & & & & & \\
\hline & CN7 & & & & & \\
\hline & CN6 & & & & \multirow{2}{*}{ D: $37 R-5 / 42 R-6$} & \\
\hline & CN5 & & & & & \\
\hline & $\mathrm{CN} 4$ & & & & \multirow{2}{*}{ D: 42R-CC/53R-3 } & \\
\hline & $\mathrm{CN} 3$ & & & & & \\
\hline & $\mathrm{CN} 2$ & & & & \multirow{2}{*}{ D: $53 R-4 / 57 R-3$} & \\
\hline & $\mathrm{CN} 1$ & & & & & \\
\hline \multirow{4}{*}{$\begin{array}{l}\mathscr{0} \\
\overline{0} \\
0 \\
.00 \\
0\end{array}$} & $\mathrm{CP} 19$ & & & & \multirow{3}{*}{ D: $58 \mathrm{R}-\mathrm{CC} / 86 \mathrm{R}-2$} & \\
\hline & $\mathrm{CP} 18$ & & & & & \\
\hline & $\mathrm{CP} 17$ & & & & & \\
\hline & CP16 & B: 15R-CC/17R-CC & & & & \\
\hline \multirow{7}{*}{$\begin{array}{c}\mathscr{D} \\
\bar{D} \\
0 \\
I I\end{array}$} & $\mathrm{CP} 15$ & & A: $11 \mathrm{R}-\mathrm{CC} / 17 \mathrm{R}-\mathrm{CC}$ & & & \\
\hline & $\mathrm{CP} 14$ & & A: $21 \mathrm{R}-1 / 22 \mathrm{R}-\mathrm{CC}$ & A: $4 \mathrm{R}-\mathrm{CC}$ & D: $88 \mathrm{R}-1,2$ & \\
\hline & $\mathrm{CP} 13$ & & & & \multirow{3}{*}{ D: $88 \mathrm{R}-1 / 91 \mathrm{R}-\mathrm{CC}$} & \\
\hline & $\mathrm{CP} 12$ & & & & & \\
\hline & CP11 & & & & & \\
\hline & $\mathrm{CP} 10$ & & & & D: $92 \mathrm{R}-1 / 93 \mathrm{R}-2$ & \\
\hline & СР9 & & & & D: 93R-CC & \\
\hline
\end{tabular}

Notes: A, B, and D indicate Holes A, B, and D, respectively. Where more than one core section is assigned to a single zone, the highest and lowest sections are listed with a slash between them. 
Table 2. Distribution of calcareous nannofossils, Site 914.

\begin{tabular}{|c|c|c|c|c|c|c|c|c|c|c|c|c|c|c|c|c|c|c|c|c|c|c|c|c|}
\hline$\underset{80}{\mathbb{Z}}$ & $\stackrel{\mathscr{\Xi}}{\mathcal{N}}$ & & 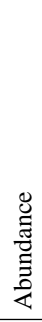 & 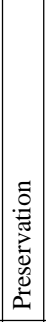 & 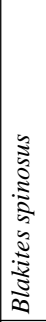 & 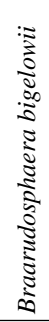 & 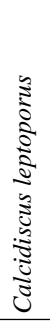 & 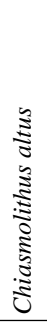 & 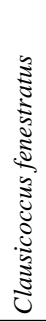 & 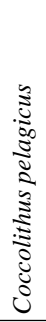 & 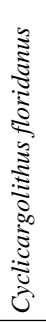 & 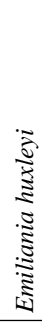 & 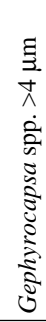 & 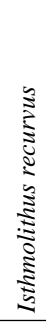 & 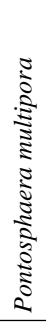 & 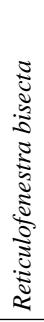 & 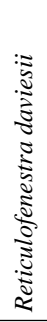 & 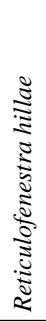 & 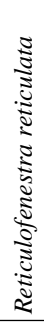 & 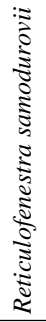 & 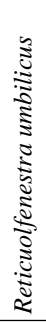 & 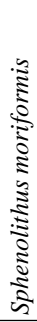 & 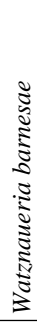 & 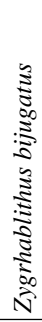 \\
\hline \multirow{13}{*}{$\begin{array}{l}\stackrel{0}{0} \\
\stackrel{0}{0} \\
\frac{\tilde{D}}{\Delta}\end{array}$} & \multirow{11}{*}{$\frac{n}{Z}$} & & & & & & & & & & & & & & & & & & & & & & & \\
\hline & & $1 \mathrm{H}-1,66$ & $\mathrm{~F}$ & $\mathrm{M}$ & . & . & $\mathrm{F}$ & . & . & $\mathrm{C}$ & . & $\mathrm{F}$ & 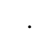 & . & . & . & . & . & . & . & . & . & & . \\
\hline & & $1 \mathrm{H}-2,66$ & $\mathrm{R}$ & M & . & . & $\mathrm{R}$ & . & . & $\mathrm{F}$ & . & $\mathrm{R}$ & . & . & . & . & . & . & . & . & . & . & & . \\
\hline & & $1 \mathrm{H}-3,66$ & $\mathrm{R}$ & M & . & . & . & . & . & $\mathrm{R}$ & . & . & . & . & . & . & . & . & . & . & . & . & . & . \\
\hline & & $1 \mathrm{H}-\mathrm{C}$ & B & & . & . & . & . & . & . & . & . & . & . & . & . & . & . & . & . & . & . & . & . \\
\hline & & $2 \mathrm{H}-2,65$ & B & & . & . & . & . & . & . & . & . & . & . & . & . & . & . & . & . & . & . & . & . \\
\hline & & $2 \mathrm{H}-3,66$ & B & & . & . & . & . & . & . & . & . & . & . & . & . & . & . & . & . & . & . & . & . \\
\hline & & $2 \mathrm{H}-4,66$ & B & & . & . & . & . & . & . & . & . & . & . & . & . & . & . & . & . & . & . & . & . \\
\hline & & 2 & $\mathrm{R}$ & $\mathrm{M}$ & . & . & . & & . & . & $\cdot$ & $\mathrm{R}$ & . & . & . & . & . & . & . & . & . & . & . & . \\
\hline & & $\mathrm{H}-\mathrm{CC}$ & $\mathrm{R}$ & $\mathrm{P}$ & . & . & . & & . & . & $\cdot$ & $\mathrm{R}$ & . & . & . & . & . & . & . & . & . & . & . & . \\
\hline & & $3 \mathrm{H}-\mathrm{CC}$ & $\mathrm{R}$ & $\mathrm{P}$ & & & & & & & . & $\mathrm{R}$ & & . & · & & & & & & & • & . & . \\
\hline & $\underline{=}$ & $\overline{152-914 B}$ & & & & & & & & & & & & & & & & & & & & & & \\
\hline & ZZ & 8R-CC & $\mathrm{R}$ & P & . & & . & $r$ & . & R & $\mathrm{r}$ & . & $\underline{\mathrm{R}}$ & . & . & $\mathrm{r}$ & $\mathrm{r}$ & $r$ & $r$ & - & $\mathrm{r}$ & $\therefore$ & r & . \\
\hline & $?$ & $13 \mathrm{R}-\mathrm{C} C$ & B & & & $\therefore$ & & & & & & & & & & & & & & & & & & \\
\hline$\infty$ & & $\overline{15 \mathrm{R}-\mathrm{C}} \mathrm{C}$ & $\mathrm{C}$ & $\mathrm{M}$ & - & . & . & $\mathrm{R}$ & $\mathrm{R}$ & $\mathrm{C}$ & $\mathrm{R}$ & & - & $\overline{\text {. }}$ & $\overline{\mathrm{R}}$ & $\overline{\mathrm{C}}$ & $\overline{\mathrm{C}}$ & $\mathrm{R}$ & & $\mathrm{R}$ & $\mathrm{R}$ & $\mathrm{R}$ & . & - \\
\hline$\overline{0}$ & 0 & $16 \mathrm{R}-2,31$ & $\mathrm{C}$ & $\mathrm{M}$ & $\mathrm{R}$ & $\mathrm{R}$ & . & $\mathrm{R}$ & . & $\mathrm{C}$ & $\mathrm{R}$ & . & . & . & $\mathrm{R}$ & $\mathrm{F}$ & $\mathrm{C}$ & $\mathrm{F}$ & . & . & $\mathrm{F}$ & . & . & $\mathrm{R}$ \\
\hline$\geqslant$ & 己 & 16R-CC & $\mathrm{C}$ & $\mathrm{M}$ & . & . & . & $\mathrm{R}$ & . & . & . & . & . & $\mathrm{R}$ & . & $\mathrm{F}$ & $\mathrm{C}$ & $\mathrm{R}$ & . & . & $\mathrm{R}$ & . & . & . \\
\hline తี & & 17R-CC & $\mathrm{F}$ & $\mathrm{P}$ & . & . & . & $\mathrm{R}$ & . & . & . & . & . & $\mathrm{R}$ & . & $\mathrm{F}$ & $\mathrm{F}$ & $\mathrm{R}$ & . & . & $\mathrm{R}$ & . & . & . \\
\hline
\end{tabular}

Note: $\mathrm{C}=$ common, $\mathrm{F}=$ few, $\mathrm{R}=$ rare, $\mathrm{B}=$ barren, $\mathrm{M}=$ moderate, and $\mathrm{P}=$ poor.

terval from this sample down to Sample 152-915A-17R-CC yielded relatively diverse nannofossil assemblages, including several agediagnostic species, such as Chiasmolithus oamaruensis, Isthmolithus recurvus, Reticulofenestra reticulata, and $R$. umbilicus. These assemblages suggest an age of late Eocene (CP15). Samples 152-915A$18 \mathrm{R}-1,70 \mathrm{~cm}$, through $21 \mathrm{R}-1,2 \mathrm{~cm}$, are barren of calcareous nannofossils. Samples 152-915A-21R-1, $4 \mathrm{~cm}$, through 22R-CC yielded generally rare and sporadic nannofossils. However, the presence of $C$. solitus and $R$. umbilicus in this interval suggests that Subzone CP14a is of middle Eocene age. Core 152-915A-23R, which overlies weathered basalt, is barren of nannofossils and probably represents an alluvial fan deposit (Larsen, Saunders, Clift, et al., 1994).

Assuming general carbonate saturation at this relatively shallow water site (present water depth $=533 \mathrm{~m}$ ), the scarcity or absence of calcareous nannofossils in CP14a appears to indicate that the sediment was deposited in a relatively shallow water environment, probably no more than $100 \mathrm{~m}$ of water. The total absence of planktonic foraminifers in this subzone (Spezzaferri, this volume) is consistent with this interpretation. The absence of both calcareous nannofossils (Table 3) and planktonic foraminifers in the presence of rare benthic foraminifers in the interval between Samples 152-915A-18R-1, 70 $\mathrm{cm}$, and $21 \mathrm{R}-1,2 \mathrm{~cm}$, may indicate that water depth was probably no more than a few tens of meters during that time. The common to abundant calcareous nannofossils in Zone CP15 (Table 3) suggest an increase in water depth, most likely over $100 \mathrm{~m}$ in this time. However, examination of the sea level curve of Haq et al. (1987) shows a large drop of sea level Zone CP15. Therefore, the increase in water depth at Site 915 in CP15 does not appear to be caused by global sea level rise but may be the result of rapid local subsidence.

\section{Site 916}

Mostly gravels were recovered for the sedimentary section at this site. The following samples were available for nannofossils analysis:
152-916A-5R-1, $60 \mathrm{~cm}$; 9R-CC; 13R-1, $79 \mathrm{~cm}$; 13R-2, $4 \mathrm{~cm}$; 13R-2, $118 \mathrm{~cm}$; 13R-2, $140 \mathrm{~cm}$; 13R-3, $72 \mathrm{~cm}$; 13R-CC; and 14R-CC. No in situ nannofossils are present in these samples.

\section{Site 917}

Sample 152-917A-1R-CC is barren of calcareous nannofossils. Core 152-917A-2R did not recover any sediment, whereas Core 152917A-3R recovered only a piece of gravel. The core catcher from Core 152-917A-4R yielded rare specimens of calcareous nannofossils, including Blackites spinosus, Chiasmolithus solitus, Cyclicargolithus floridanus, Reticulofenestra bisecta, R. daviesii, R. hillae, and $R$. umbilicus. This sample can be assigned to Subzone CP14a (middle Eocene) based on the presence of $C$. solitus and $R$. umbilicus. Core 152-917A-5R did not recover any sediment. Core 152-917A-6R is barren of calcareous nannofossils. Cores 152-917A-7R through $101 \mathrm{R}$ are from a basalt sequence. The rest of the cores (152-917A$102 \mathrm{R}$ through $110 \mathrm{R}$ ) are from a metamorphosed sediment sequence of unknown age. The following samples were analyzed for nannofossils: 152-917A-102R-3, $20 \mathrm{~cm}$; 103R-1, $10 \mathrm{~cm} ; 103 \mathrm{R}-4,15 \mathrm{~cm}$; 104R-1, $90 \mathrm{~cm}$; 104R-4, $20 \mathrm{~cm}$; 105R-1, $65 \mathrm{~cm}$; and 110R-1, $31 \mathrm{~cm}$. No nannofossils were found in these samples.

\section{Site 918}

Four holes were drilled at this site. Holes 918A and 918D yielded the longest and most important sedimentary sequence drilled by Leg 152. Core 152-918D-4R begins at the same stratigraphic level where Hole 918A terminated. Nannofossil range charts for the entire Hole 918A and Cores 152-918D-4R through 97R are constructed (Tables $4,5)$.

Samples 152-918A-1H-1, $1 \mathrm{~cm}$, and $1 \mathrm{H}-1,30 \mathrm{~cm}$, contain common to abundant Emiliania huxleyi and Coccolithus pelagicus (Table 4). These samples can be assigned to the Holocene based on the bio- 
Table 3. Distribution of calcareous nannofossils, Hole 915A.

\begin{tabular}{|c|c|c|c|c|c|c|c|c|c|c|c|c|c|c|c|c|c|c|c|c|c|c|c|c|c|c|}
\hline$\frac{8}{4}$ & $\stackrel{\mathscr{0}}{\mathrm{O}}$ & $\begin{array}{l}\text { Core, section } \\
\text { interval }(\mathrm{cm})\end{array}$ & 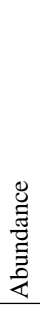 & 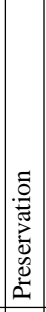 & 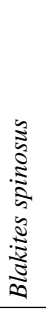 & 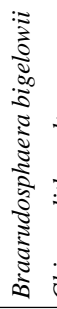 & 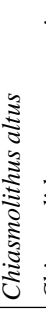 & 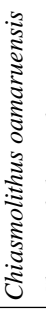 & & 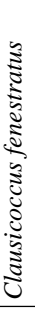 & 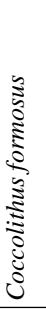 & 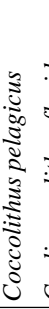 & 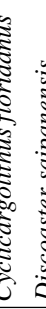 & 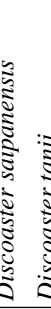 & & 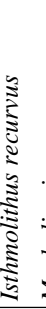 & 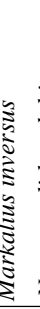 & 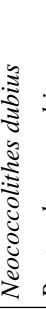 & 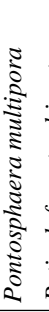 & 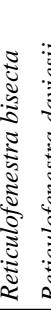 & 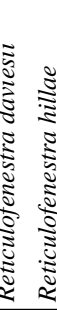 & 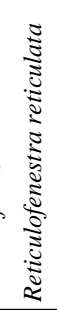 & 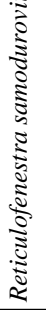 & 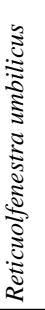 & 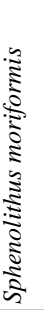 & 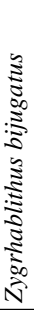 \\
\hline ? & $?$ & $\begin{array}{l}\text { 152-915A } \\
1 \mathrm{R}-\mathrm{CC}\end{array}$ & B & & & & & & & & & & & & & & & & & & & & & & & \\
\hline \multirow{6}{*}{ 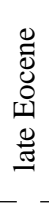 } & \multirow{6}{*}{$\frac{n}{8}$} & 11R-CC & $\mathrm{R}$ & $\mathrm{P}$ & . & & & & & . & & $\mathrm{R}$ & & & & $\mathrm{R}$ & & . & & & $\mathrm{R} \quad \mathrm{R}$ & & & & . & \\
\hline & & $14 \mathrm{R}-\mathrm{CC}$ & A & M & . & . & $\mathrm{R}$ & . & . & . & . & $\mathrm{F}$ & . & . & & $\mathrm{R}$ & . & . & $\mathrm{R}$ & $\mathrm{R}$ & C $\mathrm{R}$ & $\mathrm{R}$ & & $\mathrm{R}$ & . & \\
\hline & & 15R-CC & A & M & . & & $\mathrm{F}$ & 1 & . & . & 1 & $\mathrm{R}$ & & $\mathrm{R}$ & & $\mathrm{R}$ & 1 & $\mathrm{R}$ & & F & $\mathrm{C}$ & $\mathrm{F}$ & $\mathrm{R}$ & $\mathrm{R}$ & $\mathrm{R}$ & $\mathrm{R}$ \\
\hline & & $16 \mathrm{R}-1,58$ & A & M & . & $\mathrm{R}$ & $\mathrm{R}$ & $\mathrm{R}$ & . & . & . & $\mathrm{C}$ & $\mathrm{R}$ & & & $\mathrm{R}$ & . & $\mathrm{R}$ & $\mathrm{R}$ & $\mathrm{F}$ & $\mathrm{C}$ & $\mathrm{C}$ & $\mathrm{R}$ & $\mathrm{R}$ & $\mathrm{R}$ & $\mathrm{R}$ \\
\hline & & 16R-CC & A & M & $\mathrm{R}$ & $\mathrm{R}$ & $\mathrm{R}$ & $\mathrm{R}$ & & $\mathrm{R}$ & $\mathrm{R}$ & $\mathrm{C}$ & & $\mathrm{R}$ & 1 & $\mathrm{R}$ & . & & $\mathrm{R}$ & $\mathrm{F}$ & A & $\mathrm{C}$ & $\mathrm{F}$ & $\mathrm{F}$ & . & $\mathrm{R}$ \\
\hline & & 17R-CC & $\underline{\mathrm{C}}$ & $\underline{G}$ & - & R & $F_{2}$ & & & &. & $\underline{F}$ & . & & & & & - . & R & $\therefore$ & C & $\mathrm{F}$ & & $\mathrm{F}$ & . & R \\
\hline \multirow{12}{*}{ ? } & \multirow{12}{*}{$?$} & $18 \mathrm{R}-1,70$ & B & . & . & & . & . & & & . & . & . & & & . & & . & . & . & . & . & & & & \\
\hline & & $18 \mathrm{R}-2,63$ & B & . & . & . & . & . & . & . & . & . & . & . & . & . & . & . & . & . & . & . & . & . & . & \\
\hline & & 18R-3, 79 & B & . & . & . & . & . & . & . & . & . & . & . & . & . & . & . & . & . & . & . & . & . & . & . \\
\hline & & 18R-CC & B & . & . & . & . & . & . & . & . & . & . & . & . & . & . & . & . & . & . & . & . & . & . & . \\
\hline & & $19 \mathrm{R}-1,74$ & B & . & . & . & . & . & . & . & . & . & . & . & . & . & . & . & . & . & . & . & . & . & . & . \\
\hline & & $19 \mathrm{R}-2,65$ & B & . & . & . & . & . & . & . & . & . & . & . & . & . & . & . & . & . & . & . & . & . & . & . \\
\hline & & $19 \mathrm{R}-3,58$ & B & . & . & . & . & . & . & . & . & . & . & . & & . & . & . & . & . & . & . & . & . & . & \\
\hline & & 19R-4, 65 & B & . & . & . & . & . & . & . & . & . & . & . & & . & . & . & . & . & . & . & . & . & . & \\
\hline & & 19R-CC & B & . & . & . & . & . & . & . & . & . & . & . & & . & . & . & . & . & . & . & . & . & . & . \\
\hline & & $20 \mathrm{R}-1,73$ & B & . & . & . & . & . & . & . & . & . & . & . & & . & . & . & . & . & . & . & . & . & . & . \\
\hline & & 20R-CC & B & . & . & . & . & . & . & . & . & . & . & . & & . & . & . & . & . & . & . & . & . & . & . \\
\hline & & $21 \mathrm{R}-1,2$ & $\frac{B}{D}$ & & - & & & & & & & & - & & & & & & & & & & & & & - \\
\hline \multirow{11}{*}{ 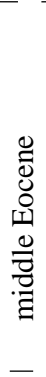 } & \multirow{10}{*}{$\frac{\stackrel{\pi}{ \pm}}{\tilde{v}}$} & 21R-1, 4 & $\mathrm{R}$ & $\mathrm{P}$ & . & & & . & $\mathrm{R}$ & . & . & . & . & & & & & . & . & . & & & & & & \\
\hline & & $21 \mathrm{R}-1,58$ & B & & . & . & . & . & $\mathrm{R}$ & . & . & . & . & . & & . & . & . & . & . & . & . & . & . & . & . \\
\hline & & 21R-2, 102 & $\mathrm{R}$ & $\mathrm{P}$ & . & . & . & . & . & . & . & . & . & . & & . & . & $\mathrm{R}$ & . & . & . & . & $\mathrm{R}$ & $\mathrm{R}$ & . & \\
\hline & & 21R-3, 64 & B & & . & . & . & . & . & . & . & . & . & . & & . & . & . & . & . & . & . & . & . & . & . \\
\hline & & $21 \mathrm{R}-4,60$ & $\mathrm{R}$ & $\mathrm{P}$ & . & . & . & . & . & . & . & . & . & . & & . & . & . & . & . & . & . & & . & . & \\
\hline & & $21 \mathrm{R}-5,25$ & B & & . & . & . & . & . & . & . & . & . & & & . & . & . & . & . & . & . & . & . & . & . \\
\hline & & 21R-CC & $\mathrm{F}$ & M & . & . & . & . & $\mathrm{R}$ & . & . & $\mathrm{R}$ & $\mathrm{R}$ & & & . & . & . & . & . & & . & $\mathrm{F}$ & $\mathrm{R}$ & . & . \\
\hline & & $22 \mathrm{R}-1,67$ & $\mathrm{R}$ & M & . & . & . & . & $\mathrm{R}$ & . & . & . & . & & & . & & . & . & . & & . & F & $\mathrm{R}$ & . & \\
\hline & & $22 \mathrm{R}-2,65$ & B & & . & . & . & . & . & . & . & . & . & & & & & . & . & . & & . & $\cdot$ & . & . & \\
\hline & & $22 \mathrm{R}-3,10$ & $\mathrm{R}$ & $\mathrm{P}$ & & & . & . & . & . & . & . & & & & . & & . & . & . & & . & $\mathrm{R}$ & . & . & . \\
\hline & $\bar{?}$ & $\begin{array}{l}22 \mathrm{R}-\mathrm{CC} \\
23 \mathrm{R}-2, \frac{6}{6}\end{array}$ & $\begin{array}{l}\mathrm{R} \\
\mathrm{B}\end{array}$ & $\mathrm{P}$ & ${ }_{-}{ }_{-}$ & & & & $\underline{\mathrm{R}}$ & & & - & - & - & & & & $\dot{.}$ & $\therefore$ & - & - & & & $\mathrm{R}$ & & . \\
\hline
\end{tabular}

Note: $\mathrm{A}=$ abundant, $\mathrm{C}=$ common, $\mathrm{F}=$ few, $\mathrm{R}=$ rare, $\mathrm{B}=$ barren, $\mathrm{M}=$ moderate, and $\mathrm{P}=$ poor.

chronology of Gard and Backman (1990). Application of this biochronology further downhole is difficult as the distribution of the assemblages appears to be significantly different from that described by Gard and Backman (1990) for the Arctic/Subarctic areas. This may be due to warmer water conditions at Site 918 than at the higher latitude sites Gard and Backman (1990) investigated. Nevertheless, the lowest occurrence of E. huxleyi in Sample 152-918A-4H-1, $65 \mathrm{~cm}$, allows the recognition of the base of Zone CN15 below this sample, which is correlated with oxygen isotope Stage 8 (Thierstein et al., 1977).

The lowest occurrence of Gephyrocapsa spp. ( $>4 \mu \mathrm{m})$ generally approximates the Pliocene/Pleistocene boundary based on low- to middle-latitude data (Wei, 1993). If this datum is applied to Site 918, the Pliocene/Pleistocene boundary may be drawn below Sample 152918A-24X-CC (Table 4). This boundary should be considered tentative because the reliability of the datum at this high latitude has not been tested. In addition, Gephyrocapsa spp. $(>4 \mu \mathrm{m})$ are generally rare and sporadic and it is difficult to determine their true first occurrence. Furthermore, the use of this datum also disagrees with the magnetostratigraphic interpretation of Larsen, Saunders, Clift, et al. (1994). Other independent biostratigraphic or isotope stratigraphic data may help resolve the Pliocene/Pleistocene boundary problem at this site.

Pseudoemiliania lacunosa occurs in Sample 152-918A-31X-CC; this suggests that the sample is no older than late Pliocene. As the lowest five samples from Hole 918A are barren of calcareous nannofossils, the position of the lower Pliocene/upper Pliocene boundary cannot be precisely determined, but is tentatively drawn below Sample 152-918A-31X-CC (Table 4).

Cores 152-918D-4R through 13R (Table 5) are either barren of nannofossils or contain rare specimens of $C$. pelagicus and Reticulofenestra producta, neither being age-diagnostic. As these cores are stratigraphically below the bottom of Hole 152-918A and overlie lower Pliocene sediments, they can be assigned a general Pliocene age. The highest occurrence of Reticulofenestra gelida (Pl. 1, Figs. 5, 6) is in Sample 152-918D-14R-1, $109 \mathrm{~cm}$, and marks the top of Zone CN11.

The highest occurrence of Discoaster quinqueramus (Pl. 1, Figs. 7,8 ) is in Sample 152-918D-24R-3, $49 \mathrm{~cm}$. This datum is commonly used to approximate the Miocene/Pliocene boundary in low to middle latitudes. As discoasters generally disappeared from high latitudes earlier, the Miocene/Pliocene boundary is most likely to be higher 
Table 4. Distribution of calcareous nannofossils, Hole 918A.

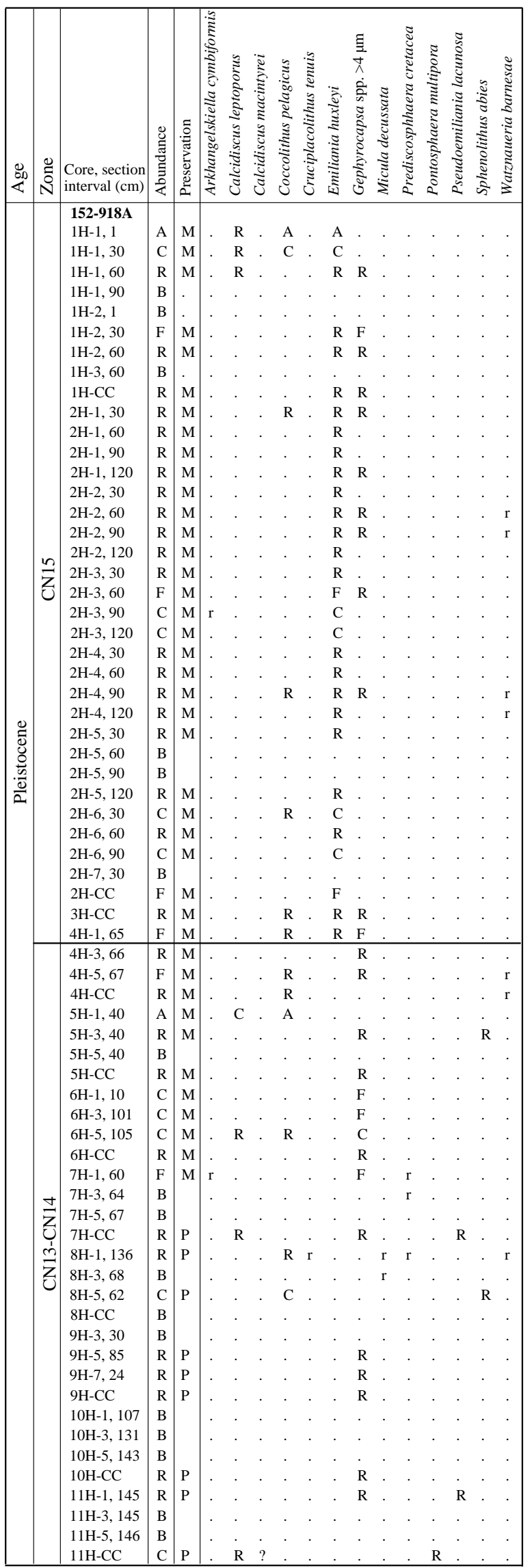

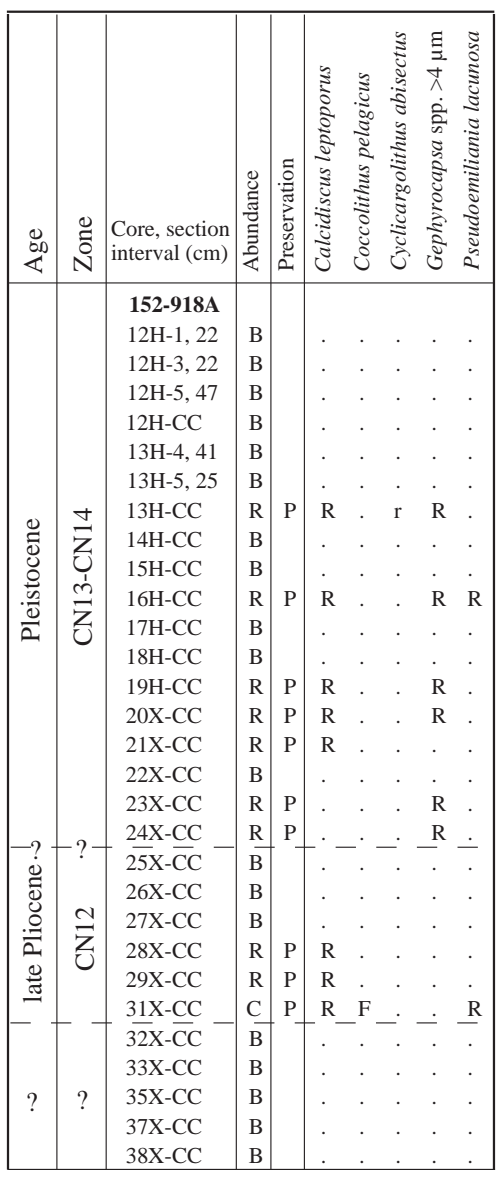

Note: $\mathrm{A}=$ abundant, $\mathrm{C}=$ common, $\mathrm{F}=$ few, $\mathrm{R}=$ rare, $\mathrm{B}=$ barren, $\mathrm{M}=$ moderate, and $\mathrm{P}=$ poor.

than indicated in Table 5. Similarly, as D. quinqueramus is rare at this high latitude and its stratigraphic range is almost certainly shorter than at lower latitudes, the precise location of the lower boundary of Zone CN9 is not known but is at least below Sample 152-918D-24RCC (Table 5).

The highest occurrence of Coccolithus miopelagicus is in Sample $152-918 \mathrm{D}-37 \mathrm{R}-5,25 \mathrm{~cm}$. This suggests that the sample is about 11 Ma in age. The highest occurrence of Cyclicargolithus floridanus is in Sample 152-918D-38R-6, $25 \mathrm{~cm}$. This datum has an age of about 11.6 Ma (Young et al., 1994). Another useful datum slightly below is the highest occurrence of Calcidiscus premacintyrei in Sample 152918D-39R-4, $18 \mathrm{~cm}$ (Pl. 2, Figs. 3, 4), which can be assigned an age of 12.1 Ma (Young et al., 1994). The lowest occurrence of Reticulofenestra gelida $(>7 \mu \mathrm{m})$ is in Sample 152-918D-40R-3, $33 \mathrm{~cm}$ (Table 5). This level is considered to be equivalent to the first occurrence of Reticulofenestra pseudoumbilicus ( $>7 \mu \mathrm{m})$, which has been correlated with Chron C5AA at $13 \mathrm{Ma}$ (Young et al., 1994).

The next important marker is the highest occurrence of Sphenolithus heteromorphus in Sample 152-918D-42R-CC. This datum has been correlated with magnetostratigraphy at low to middle latitudes with an age of about 13.6 Ma (Young et al., 1994). As sphenoliths generally preferred relatively warm waters, the stratigraphic range of S. heteromorphus is most likely to be shorter at this high latitude, that is, the highest occurrence of this species at Site 918 should be older than 13.6 Ma. The lowest occurrence of Calcidiscus premacintyrei is in Sample 152-918D-52R-5, $79 \mathrm{~cm}$, and suggests an age of about 17.4 Ma based on biomagnetostratigraphic correlation in the midlatitude North Atlantic (Gartner, 1992). 
Table 5. Distribution of calcareous nannofossils, Hole 918D.

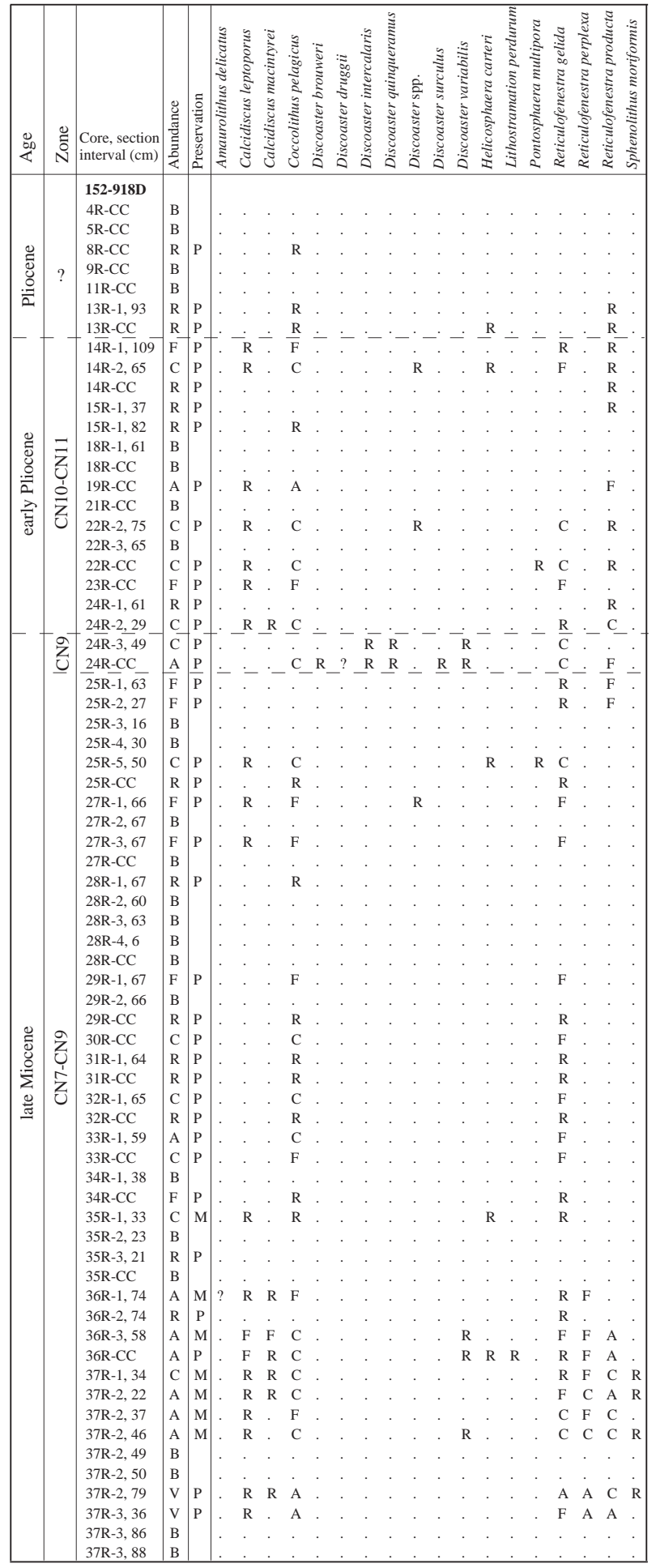

\begin{tabular}{|c|c|c|c|c|c|c|c|c|c|c|c|c|c|c|c|c|c|c|c|c|c|c|}
\hline 总 & 8 & $\begin{array}{l}\text { Core, section } \\
\text { interval }(\mathrm{cm})\end{array}$ & 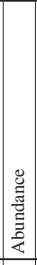 & 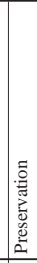 & 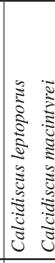 & 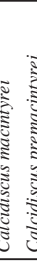 & 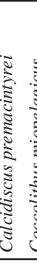 & & 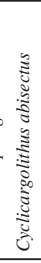 & 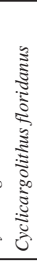 & & 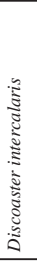 & 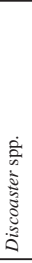 & 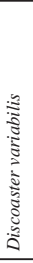 & & 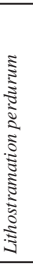 & 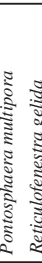 & 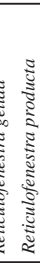 & 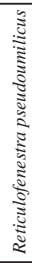 & 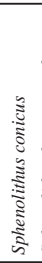 & & 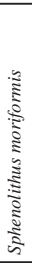 \\
\hline & & 152-918D & & & & & & & & & & & & & & & & & & & & \\
\hline & & 37R-5, & A & $\mathrm{P}$ & . & & & & & & . & & & & $\mathrm{R}$ & & & $\mathrm{F}$ & C & & & $\mathrm{R}$ \\
\hline & & $37 \mathrm{R}-5,93$ & $\mathrm{~V}$ & P & . & . & $\mathrm{F}$ & $\mathrm{R} \quad \mathrm{C}$ & & & . & & $\mathrm{R}$ & $\mathrm{R}$ & $\mathrm{R}$ & & . $\mathrm{R}$ & R. & $\mathrm{R}$ & . & & . \\
\hline & & $38 \mathrm{R}-1,59$ & C & $\mathrm{P}$ & . & . & c & C F & & . & . & & . & & $\mathrm{R}$ & . & . $\mathrm{F}$ & F. & . & . & & $\mathrm{R}$ \\
\hline & & $38 \mathrm{R}-2,61$ & C & $P$ & . . & & c & C F & & & & $\mathrm{R}$ & . & & $\mathrm{R}$ & . & . $\mathrm{C}$ & C. & r. & & & . \\
\hline & & $38 \mathrm{R}-3,62$ & A & $P$ & . . & & c & C C & : & . & . & . & & . & & & . $A$ & A. & & . & & \\
\hline & & $38 \mathrm{R}-4,17$ & A & P & . . & & c & $\mathrm{C} \quad \mathrm{C}$ & & & & $\mathrm{R}$ & & . & & & . $\mathrm{A}$ & A. & & . & & \\
\hline & & $38 \mathrm{R}-4,54$ & A & $P$ & . $\mathrm{R}$ & $\mathrm{R}$ & c & C C & & . & . & . & . & & & . & . $A$ & & . & . & & $\mathrm{R}$ \\
\hline & & $38 \mathrm{R}-5,15$ & A & $\mathrm{P}$ & . & & $c$ & C C & & & . & . & $\mathrm{R}$ & & $\mathrm{R}$ & . & . $\mathrm{C}$ & C. & . & . & & $\mathrm{R}$ \\
\hline & & $38 \mathrm{R}-6,25$ & A & P & . & & c & C C & $=R$ & $\mathrm{R}$ & . & . & . & & $\mathrm{R}$ & . & . $\mathrm{C}$ & C. & . & & & $\mathrm{R}$ \\
\hline & & 38R-CC & C & P & . & & c & C C & $=$ & $\mathrm{R}$ & . & . & & . & . & . & . $\mathrm{C}$ & C. & & . & & \\
\hline & & $39 \mathrm{R}-1,78$ & A & $\mathrm{M}$ & . & & I & F C & & $\mathrm{R}$ & & & & . & & & . C & & & . & & \\
\hline & & $39 \mathrm{R}-2,95$ & A & M & $\mathrm{R}$ & & $\mathrm{I}$ & F C & $\mathrm{R}$ & $\mathrm{R}$ & . & & & & & . & . $\mathrm{F}$ & F. & & . & & $\mathrm{R}$ \\
\hline & & $39 \mathrm{R}-3,93$ & A & $P$ & $\mathrm{R}$ & $\mathrm{R}$ & 1 & F C & $=$ & $\mathrm{R}$ & & C & $\mathrm{R}$ & $\mathrm{R}$ & & . & $\mathrm{F}$ & & . & & & . \\
\hline & & $39 \mathrm{R}-4,18$ & $\mathrm{~V}$ & M & . & $\mathrm{R}$ & $\mathrm{R}$ & F A & A $R$ & $\mathrm{R}$ & & $\mathrm{F}$ & & $\mathrm{R}$ & $\mathrm{R}$ & 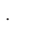 & $\mathrm{F}$ & & . & & & \\
\hline & & $39 \mathrm{R}-5,80$ & $\mathrm{~V}$ & M & $\mathrm{R}$ & $\mathrm{R}$ & $\mathrm{R} \quad \mathrm{F}$ & $\mathrm{R} \quad \mathrm{A}$ & $A R$ & $\mathrm{R}$ & . & $\mathrm{R}$ & & $\mathrm{R}$ & $\mathrm{R}$ & & $\mathrm{R} C$ & C. & & . & & $\mathrm{R}$ \\
\hline & & $39 \mathrm{R}-6,60$ & V & M & . & . $\mathrm{R}$ & $\mathrm{R} \quad \mathrm{F}$ & $\mathrm{R} \quad \mathrm{A}$ & $A R$ & $\mathrm{R}$ & . & $\mathrm{R}$ & $\mathrm{R}$ & $\mathrm{R}$ & F & & . A & A. & & . & & $\mathrm{F}$ \\
\hline & Z & 39R-CC & V & M & & & $\mathrm{F} F$ & $\mathrm{R} \quad \mathrm{A}$ & $A F$ & $\mathrm{R}$ & & $\mathrm{R}$ & $\mathrm{R}$ & & $\mathrm{R}$ & & . $\mathrm{C}$ & & & . & & $\mathrm{R}$ \\
\hline & & $40 \mathrm{R}-2,41$ & A & $P$ & $\mathrm{R}$ & $\mathrm{R}$ & R $\mathrm{I}$ & $\mathrm{F} \quad \mathrm{A}$ & A $R$ & $\mathrm{R}$ & & $\mathrm{R}$ & . & & $\mathrm{F}$ & . & . & & & . & & . \\
\hline & z & $40 \mathrm{R}-3,33$ & V & M & . & $\mathrm{R}$ & $\mathrm{R} \quad \mathrm{I}$ & $\mathrm{F} \quad \mathrm{A}$ & $A F$ & $\mathrm{R}$ & & $\mathrm{R}$ & $\mathrm{R}$ & & $\mathrm{R}$ & . & $\mathrm{R} F$ & F. & . & & & . \\
\hline & & $40 \mathrm{R}-4,50$ & $\mathrm{~V}$ & M & $\mathrm{R}$ & $\mathrm{R}$ & $\mathrm{R} \quad \mathrm{I}$ & $\mathrm{F} \quad \mathrm{A}$ & A C & $\mathrm{F}$ & & $\mathrm{F}$ & . & . & $\mathrm{R}$ & & . . & . & & . & & \\
\hline & & 40R-6, 16 & $\mathrm{v}$ & $P$ & . & & $\mathrm{R} \quad \mathrm{I}$ & $\mathrm{F} \quad \mathrm{A}$ & $A R$ & $\mathrm{R}$ & & $\mathrm{R}$ & . & & $\mathrm{F}$ & . & . & . & . & . & & \\
\hline & & 40R-CC & $\mathrm{V}$ & P & $\mathrm{R}$ & $\mathrm{R} \quad \mathrm{R}$ & $\mathrm{R} \quad \mathrm{I}$ & $\mathrm{F} \quad \mathrm{A}$ & $A R$ & $\mathrm{R}$ & & $\mathrm{F}$ & - & & $\mathrm{R}$ & & $\mathrm{R}$ & . & . & . & & $\mathrm{R}$ \\
\hline & & $41 \mathrm{R}-1,91$ & $\mathrm{~V}$ & M & $\mathrm{R} \quad \mathrm{R}$ & $\begin{array}{ll}\mathrm{R} & \mathrm{R}\end{array}$ & $\mathrm{R} \quad \mathrm{I}$ & $\mathrm{F} \quad \mathrm{A}$ & $A R$ & $\mathrm{~F}$ & & $\mathrm{R}$ & $\mathrm{R}$ & . & $\mathrm{R}$ & & $\mathrm{R}$ & . & . & . & & $\mathrm{R}$ \\
\hline \% & & $41 \mathrm{R}-2,9$ & V & M & . & . & . 1 & F A & $A F$ & C & . & . & $\mathrm{R}$ & & $\mathrm{R}$ & . & . & . & . & & & . \\
\hline$\sum_{0}^{2}$ & & $41 \mathrm{R}-3,120$ & V & M & . & . & c & C A & $A R$ & $\mathrm{~F}$ & . & & $\mathrm{R}$ & . & $\mathrm{F}$ & . & $\mathrm{R}$ & . & & . & & $\mathrm{R}$ \\
\hline $\bar{z}$ & & 41R-4, 109 & V & M & . & $\mathrm{R}$ & $\mathrm{R}$ & $\mathrm{C} A$ & $A F$ & C & & $\mathrm{R}$ & . & $\mathrm{R}$ & F & & $\mathrm{R}$ & . & . & . & & \\
\hline है & & $41 \mathrm{R}-5,70$ & A & M & & & & C A & $A R$ & $\mathrm{R}$ & & $\mathrm{R}$ & . & & $\mathrm{R}$ & & $\mathrm{R}$ & . & . & . & & $\mathrm{R}$ \\
\hline & & 41R-CC & V & M & $\mathrm{R}$ & $\mathrm{R} \quad \mathrm{R}$ & $\mathrm{R} \quad \mathrm{I}$ & F A & $A R$ & $\mathrm{R}$ & & $\mathrm{R}$ & . & . & $\mathrm{R}$ & . & $\mathrm{R}$ & . & . & . & & $\mathrm{R}$ \\
\hline & & $42 \mathrm{R}-1,71$ & V & M & . & . . . & . 1 & $\mathrm{~F} \quad \mathrm{~A}$ & $A R$ & $\mathrm{R}$ & & $\mathrm{R}$ & . & & $\mathrm{F}$ & . & . & . & . & & & $\mathrm{F}$ \\
\hline & & $42 \mathrm{R}-2,65$ & V & M & . & . & $\mathrm{F}$ & A & $A R$ & $\mathrm{R}$ & & $\mathrm{R}$ & & $\mathrm{R}$ & F & & $\mathrm{R}$ & . & & & & . \\
\hline & & $42 \mathrm{R}-3,54$ & V & M & . & & . $\mathrm{F}$ & A & & $\mathrm{R}$ & & $\mathrm{R}$ & $\mathrm{R}$ & $\mathrm{R}$ & $\mathrm{F}$ & & $\mathrm{R}$ & . & . & . & & . \\
\hline & & $42 \mathrm{R}-4,63$ & V & M & . & $\mathrm{R}$ & $\mathrm{R} F$ & $\mathrm{R} \quad \mathrm{A}$ & $A R$ & $\mathrm{R}$ & & $\mathrm{R}$ & $\mathrm{R}$ & & $\mathrm{R}$ & & $\mathrm{R}$ & . & . & . & & . \\
\hline & & $42 \mathrm{R}-5,96$ & V & M & & & & A & $A R$ & $\mathrm{R}$ & & $\mathrm{R}$ & & & F & & $\mathrm{R}$ & . & . & . & & 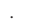 \\
\hline & & $42 \mathrm{R}-6,68$ & $\mathrm{~V}$ & M & . & $\mathrm{R}$ & $\mathrm{R} \quad \mathrm{I}$ & A & $A R$ & $\mathrm{~F}$ & & $\mathrm{R}$ & & & R & & . & & & . & & \\
\hline & & 42R-CC & $\mathrm{V}$ & M & . & & & A & $\mathrm{A} R$ & C & . & . & & $R$ & $\mathrm{R}$ & . & . & . & . & & $\mathrm{R}$ & \\
\hline & & $43 \mathrm{R}-1,72$ & V & M & & $\mathrm{R}$ & $\mathrm{R}$. & A & A. & C & . & & $\mathrm{R}$ & & $\mathrm{F}$ & & $\mathrm{R}$ & . & . & & $\mathrm{R}$ & $\mathrm{R}$ \\
\hline & & $43 \mathrm{R}-2,52$ & $\mathrm{~V}$ & M & . & & . & R A & A. & $\mathrm{R}$ & . & & & . & $\mathrm{R}$ & & . & . & & & $\mathrm{R}$ & $\mathrm{R}$ \\
\hline & & 43R-CC & V & M & . & . & . & A & A. & . & . & . & $\mathrm{R}$ & . & $\mathrm{R}$ & . & . & . & & & $\mathrm{R}$ & $\mathrm{R}$ \\
\hline & & $44 \mathrm{R}-1,61$ & V & M & . & . & . 1 & A & A & $\mathrm{R}$ & & . & $\mathrm{R}$ & & . & & . & . & . & & $\mathrm{R}$ & $\mathrm{R}$ \\
\hline & & $44 \mathrm{R}-2,67$ & V & M & $\mathrm{R}$ & $\mathrm{R}$ & $\mathrm{R} \quad \mathrm{I}$ & $\mathrm{V}$ & $v$ & C & & & $\mathrm{R}$ & & & $\mathrm{R}$ & . & . & . & & $\mathrm{R}$ & $\mathrm{R}$ \\
\hline & & $44 \mathrm{R}-3,64$ & V & M & . & . & . $\mathrm{F}$ & $\mathrm{R} \quad \mathrm{A}$ & & C & . & & $\mathrm{R}$ & & $\mathrm{R}$ & . & . & . & . & & $\mathrm{R}$ & \\
\hline & & $44 R-4,66$ & V & M & . & & . $\mathrm{F}$ & $\mathrm{R} \quad \mathrm{A}$ & A. & C & . & & $\mathrm{R}$ & . & $\mathrm{R}$ & & . & & & . & & $\mathrm{R}$ \\
\hline & & $44 \mathrm{R}-5,65$ & V & M & . & $\mathrm{R}$ & $\mathrm{R} \quad \mathrm{I}$ & A & A. & $\mathrm{R}$ & . & . & $\mathrm{R}$ & . & $\mathrm{R}$ & $\mathrm{R}$ & . & . & . & . & & \\
\hline & U & 44R-CC & V & M & $\mathrm{R}$ & $\begin{array}{ll}\mathrm{R} & \mathrm{R}\end{array}$ & $\mathrm{R} F$ & A & A & C & . & $\mathrm{R}$ & $\mathrm{R}$ & & . & . & . & . & . & & $\mathrm{R}$ & \\
\hline & m & $47 \mathrm{R}-1,49$ & C & P & . & . & . $\mathrm{F}$ & C & $=$ & $\mathrm{F}$ & . & $\mathrm{R}$ & $\mathrm{R}$ & $\mathrm{R}$ & . & . & . & . & . & & & . \\
\hline & U & $47 \mathrm{R}-2,66$ & A & P & . & . & $\mathrm{F}$ & A & A & $\mathrm{F}$ & . & $\mathrm{R}$ & $\mathrm{R}$ & $\mathrm{R}$ & . & & . & . & . & & $\mathrm{R}$ & $\mathrm{R}$ \\
\hline & & $51 \mathrm{R}-1,69$ & A & $\mathrm{P}$ & . & & . & A & A. & $\mathrm{R}$ & . & & $\mathrm{R}$ & . & & $\mathrm{R}$ & . & & & & $\mathrm{R}$ & \\
\hline & & $51 \mathrm{R}-2,51$ & V & M & . & & $\mathrm{R}$ & $\mathrm{V}$ & $v$ & F & & $\mathrm{R}$ & $\mathrm{R}$ & $\mathrm{R}$ & $\mathrm{R}$ & . & . & . & . & & F & \\
\hline & & $51 \mathrm{R}-3,75$ & A & M & $\mathrm{R}$ & $\mathrm{R}$ & $\mathrm{F}$ & A & 4 & $\mathrm{R}$ & & $\mathrm{R}$ & F & & $\mathrm{F}$ & . & . & . & . & & $\mathrm{R}$ & \\
\hline & & $51 \mathrm{R}-4,28$ & A & M & . & $\mathrm{R}$ & $\mathrm{R}$ & $\mathrm{C}$ & c & $\mathrm{F}$ & & . & $\mathrm{F}$ & $\mathrm{R}$ & & . & . & . & . & & $\mathrm{F}$ & $\mathrm{R}$ \\
\hline & & $52 \mathrm{R}-5,79$ & V & M & . & & $\mathrm{R}$ & $\mathrm{V}$ & $\mathrm{v}$ & C & . & & $\mathrm{R}$ & $\mathrm{R}$ & $\mathrm{F}$ & & $\mathrm{R}$ & . & . & & $\mathrm{F}$ & $\mathrm{R}$ \\
\hline & & $53 \mathrm{R}-1,57$ & V & M & . & & . & A & A & C & & . & $\mathrm{R}$ & . & $\mathrm{F}$ & & . & & & . & $\mathrm{R}$ & \\
\hline & & $53 \mathrm{R}-2,62$ & A & M & . & . & . & C & C. & C & & & $\mathrm{R}$ & & & . & . & . & . & & $\mathrm{R}$ & $\mathrm{R}$ \\
\hline & & $53 \mathrm{R}-3,77$ & V & M & & & & V & $\mathrm{v}$ & C & & & $\mathrm{R}$ & & $\mathrm{F}$ & & & & & & $\mathrm{R}$ & $\mathrm{R}$ \\
\hline & & $53 \mathrm{R}-4,77$ & $\mathrm{~V}$ & M & & & & $\mathrm{V}$ & V & A & & & $\mathrm{F}$ & & & & . & . & & & & \\
\hline & & $53 \mathrm{R}-5,62$ & A & M & . & & & A & 4 & C & & & $\mathrm{R}$ & & $\mathrm{F}$ & . & . & . & . & & & $\mathrm{R}$ \\
\hline & & $53 \mathrm{R}-6,71$ & A & M & . & & . & A & 4 & C & & & $\mathrm{R}$ & $\mathrm{R}$ & $\mathrm{R}$ & & . & & & & & $\mathrm{R}$ \\
\hline & & 53R-CC & A & M & . & & & A & 4 & C & . & & $\mathrm{F}$ & & & . & . & . & . & & & \\
\hline & & $54 \mathrm{R}-\mathrm{CC}$ & A & M & . & & . & A & 4 & C & . & & F & & & . & . & . & . & & & $\mathrm{R}$ \\
\hline & & $55 \mathrm{R}-1,38$ & V & M & . & & & A & A & C & & & F & & & . & . & . & . & $\mathrm{R}$ & & . \\
\hline & & $55 \mathrm{R}-2,62$ & V & M & & & & $\mathrm{V}$ & $\mathrm{v}$ & $\mathrm{R}$ & & & $\mathrm{F}$ & & & & . & & & $\mathrm{R}$ & & \\
\hline & z & $55 \mathrm{R}-3,111$ & V & M & . & & . & $\mathrm{V}$ & v & $\mathrm{F}$ & & & F & . & & & . & & & . & & \\
\hline & I & $55 \mathrm{R}-4,74$ & V & M & & & & $\mathrm{V}$ & $\mathrm{v}$ & $\mathrm{R}$ & $\mathrm{R}$ & & C & & $\mathrm{R}$ & & & . & . & & & $\mathrm{R}$ \\
\hline & $\bar{z}$ & $55 \mathrm{R}-5,78$ & $\mathrm{~V}$ & M & & & & $\mathrm{V}$ & & $\mathrm{R}$ & $\mathrm{R}$ & & C & & & & & . & & & & $\mathrm{R}$ \\
\hline & 0 & $55 \mathrm{R}-6,24$ & $\mathrm{~V}$ & M & . & & & $\mathrm{V}$ & $\mathrm{v}$ & . & $\mathrm{R}$ & & $\mathrm{F}$ & & & & & . & & & & \\
\hline & & $55 \mathrm{R}-\mathrm{CC}$ & F & $\mathrm{P}$ & . & & & $\mathrm{F}$ & F & $\mathrm{F}$ & & & & & & & & & & & & $\mathrm{R}$ \\
\hline & & $57 \mathrm{R}-1,87$ & V & M & . & & & $\mathrm{V}$ & $V F$ & A & $\mathrm{R}$ & & $\mathrm{F}$ & & & & . & & & . & & $\mathrm{R}$ \\
\hline & & $57 \mathrm{R}-2,86$ & $\mathrm{v}$ & M & & & & $\mathrm{V}$ & $\mathrm{V} F$ & A & & & & & & & & . & & & & . \\
\hline & & $57 \mathrm{R}-3,34$ & A & & . & & & A & $A R$ & $\mathrm{R}$ & & & $\mathrm{R}$ & & & & & & & & & \\
\hline
\end{tabular}


Table 5 (continued).

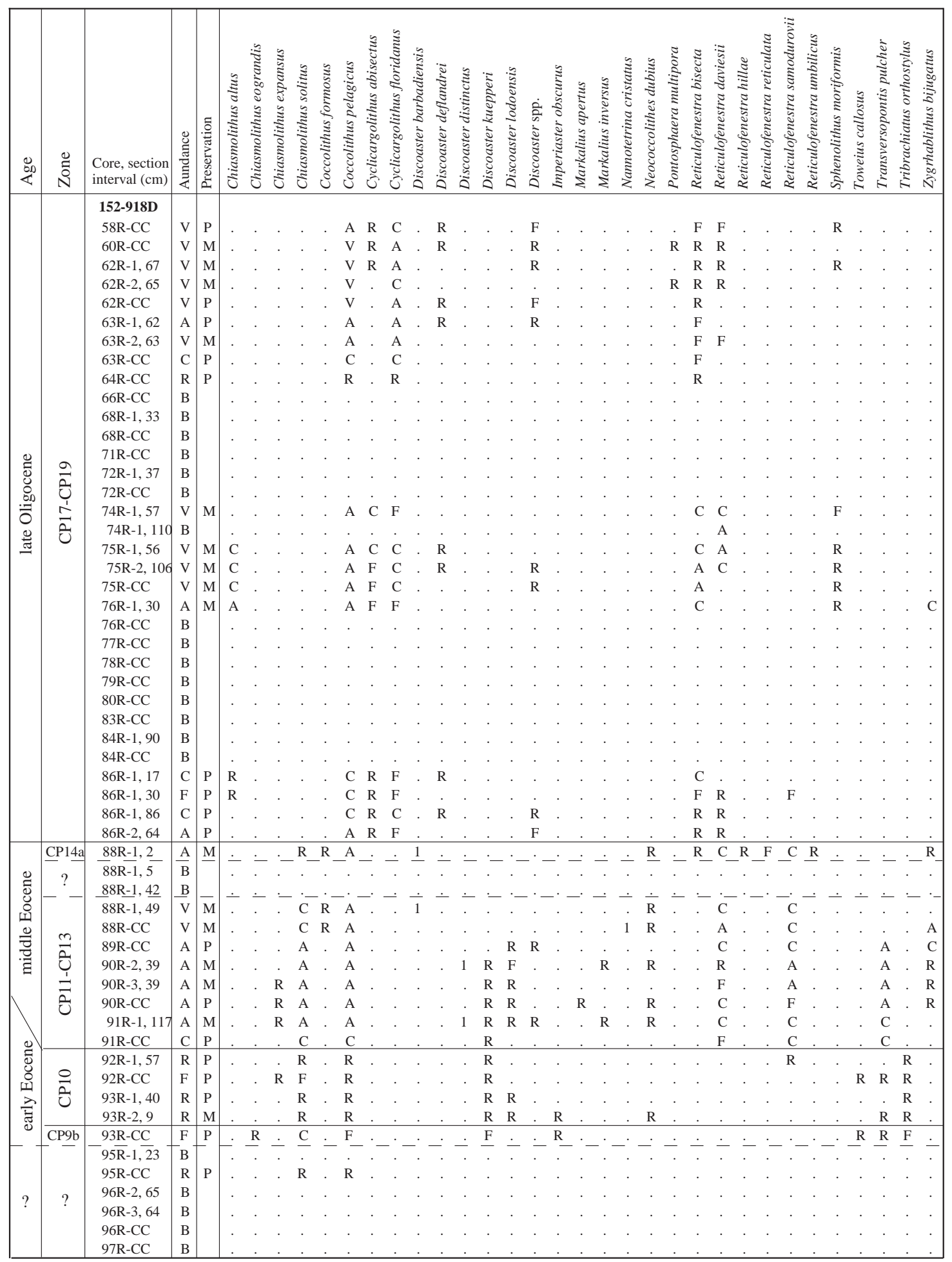

Note: $\mathrm{V}=$ very abundant, $\mathrm{A}=$ abundant, $\mathrm{C}=$ common, $\mathrm{F}=$ few, $\mathrm{R}=$ rare, $\mathrm{B}=$ barren, $\mathrm{M}=$ moderate, and $\mathrm{P}=$ poor. 
The CN2/CN3 zonal boundary, which is defined by the lowest occurrence of Sphenolithus heteromorphus, is drawn between Samples 152-918D-53R-3, $77 \mathrm{~cm}$, and 53R-4, $77 \mathrm{~cm}$. This boundary has an age of about 18.2 Ma according to biomagnetostratigraphic calibration at Deep Sea Drilling Project (DSDP) Site 609 (Gartner, 1992). The occurrence of Sphenolithus conicus in Samples 152-918D-55R$1,38 \mathrm{~cm}$, and 55R-2, $62 \mathrm{~cm}$, suggests that the samples may belong to Zone CN1 (Perch-Nielsen, 1985; Gartner, 1992).

Upper Oligocene assemblages were encountered in the interval between Samples 152-918D-58R-CC and 86R-2, $64 \mathrm{~cm}$. This is recognized by the presence of Reticulofenestra bisecta and $R$. daviesii in the absence of $R$. umbilicus and Isthmolithus recurvus. The highest occurrence of Chiasmolithus altus in Sample 152-918D-75R-1, 56 $\mathrm{cm}$ (Pl. 2, Fig. 11), may suggest an age around $27 \mathrm{Ma}$ assuming that this datum has about the same age as in the southern high latitudes (Wei and Wise, 1992). The intervals from Cores 152-918D-66R through $72 \mathrm{R}$ and $76 \mathrm{R}$ through $84 \mathrm{R}$ are barren of calcareous nannofossils and were interpreted as turbidite deposits (see Larsen, Saunders, Clift, et al., 1994).

Chiasmolithus solitus, Reticulofenestra reticulata (Pl. 2, Fig. 12), and $R$. umbilicus are present in Sample 152-918D-88R-1, $2 \mathrm{~cm}$. This indicates a Subzone of CP14a (middle Eocene) for the sample. Thus, a significant hiatus (8-10 m.y.) exists above this sample. Samples 152-918D-88R-1, $5 \mathrm{~cm}$, and 88R-1, $42 \mathrm{~cm}$, are barren of nannofossils. This interval contains volcanic ash, glauconites, and manganese oxides (Larsen, Saunders, Clift, et al., 1994), and may represent additional hiatuses.

The interval between Samples 152-918D-88R-1, $49 \mathrm{~cm}$, and 91R$\mathrm{CC}$ can be placed in Zones CP11-CP13 based on the absence of Reticulofenestra umbilicus and Tribrachiatus orthostylus. This age assignment is supported by the presence of Nannotetrina cristata in Sample 152-918D-88R-CC (Table 5; Pl. 3, Fig. 8), the highest occurrence of Discoaster lodoensis in Sample 152-918D-89R-CC, and the highest occurrence of Discoaster kuepperi in Sample 152-918D90R-2, $39 \mathrm{~cm}$ (Pl. 3, Fig. 7).

The highest occurrence of Tribrachiatus orthostylus is in Sample 152-918D-92R-1, $57 \mathrm{~cm}$, and this datum defines the top of Zone CP10. The base of this zone is placed below Sample 152-918D-93R$2,9 \mathrm{~cm}$, where the lowest occurrence of D. lodoensis is located. Sample 152-918D-93R-CC contains T. orthostylus and no D. lodoensis, and thus can be assigned to Subzone CP9b. Imperiaster obscurus occurs in Samples 152-918D-93R-2, $9 \mathrm{~cm}$, and 93R-CC (Table 5). Müller (1976) previously proposed a zone defined by the range of this species. Her correlation of this zone with the early Eocene is confirmed by the standard nannofossil zones recognized here.

\section{Site 919}

Two holes were drilled at this site. Core 152-919A-10H overlaps with Core 152-919B-3H. A nannofossil range chart for the entire hole 152-919A and Cores 152-919B-3H through $8 \mathrm{H}$ is presented in Table 6.

Emiliania huxleyi occurs downhole to Sample 152-919A-4H-5, $72 \mathrm{~cm}$, and suggests an age of $0.26 \mathrm{Ma}$, or oxygen isotope Stage 8 , as confirmed by the oxygen isotope stratigraphy of Flower (this volume). The next useful datum is the highest occurrence of Pseudoemiliania lacunosa in Sample 152-919A-7H-5, $65 \mathrm{~cm}$. This datum defines the $\mathrm{CN} 14 \mathrm{a} / \mathrm{CN} 14 \mathrm{~b}$ boundary with an age of $0.45 \mathrm{Ma}$.

Gephyrocapsa spp. (>4 $\mu \mathrm{m})$ occurs sporadically down to the last core in Hole 919B and may suggest that the oldest sediment is still of Pleistocene age. Shipboard identification of Calcidiscus macintyrei in one sample (152-919B-6H-CC) led to the placement of Pliocene/ Pleistocene boundary near this level. However, those specimens of " $C$. macintyrei" are problematic because they are actually smaller than $10 \mu \mathrm{m}$ (Pl. 1, Fig. 4), and thus should be better placed in Calcidiscus leptoporus. This nannofossil stratigraphic interpretation is consistent with the strontium isotope stratigraphy (Israelson and
Spezzaferri, this volume) and magnetostratigraphy (Ali and Vandamme, this volume), which suggests an age between the Brunhes and the Jaramillo ( 0.9 Ma) for the bottom of Hole 918B.

\section{SOME PALEOCLIMATIC AND PALEOCEANOGRAPHIC REMARKS}

Eocene nannofossil assemblages from the Leg 152 sites are relatively diverse and contain a number of warm water taxa, such as several species of discoasters and Coccolithus formosus. The abundance of cool water taxa, such as species of Chiasmolithus, is relatively low. These assemblages closely resemble those in the middle and even low latitudes. The relatively low biogeographic gradients suggest that the thermal gradients between the high northern latitudes and the low latitudes during the Eocene were considerably lower than today. The high northern latitudes apparently cooled significantly by the early Oligocene, as most warm water taxa had disappeared from the area, and cool water taxa (Chiasmolithus altus and Reticulofenestra daviesii) had become prominent.

A comparison of the nannofossil assemblages from the northern high latitudes with those in the southern high latitudes (Pospichal and Wise, 1990; Wei and Wise, 1990) shows a relatively symmetric bipolar biogeographic distribution during the early and middle Eocene. By the late Eocene, warm water taxa, such as discoasters, virtually disappeared from the southern high latitudes, whereas they were still present in the northern high latitudes. This may suggest that a protocircumpolar current had been established around Antarctica by the late Eocene. Since this time, differences in nannofossil assemblages between the northern high latitudes and southern high latitudes progressively increased. Warm-water taxa were totally absent, and cool water taxa dominated the southern high latitudes in the Oligocene and Miocene, whereas warm-water taxa were present, although sporadically, through the Pliocene in the northern high latitudes. Nannofossils were virtually absent from the southern high latitudes in the Neogene whereas they persisted to the present in the northern high latitudes. All this clearly reflects the progressive intensification of the cold circum-polar current around Antarctica, a condition that did not exist in the northern high latitudes.

Discoasters are consistently present from Sample 152-918D-39R$3,93 \mathrm{~cm}$, downhole in the Miocene (Table 5). Above this sample, discoasters are virtually absent. This level is interpreted as the time when the cold East Greenland Current began to flow through the Denmark Strait, abruptly cooling the southeast Greenland Margin and driving warm-water dwelling discoasters away from the region. This event is dated as about 12 Ma based on the highest occurrences of Cyclicargolithus floridanus and Calcidiscus premacintyrei in the lower part of this core.

The onset of North Atlantic Deep Water (NADW) flow through the Irminger Basin, as identified by glauconitic hardgrounds in Cores 152-918D-37R and 38R (Larsen, Saunders, Clift, et al., 1994), occurred about 0.5 m.y. later than the interpreted onset of East Greenland Current, that is, $11.5 \mathrm{Ma}$ based on the highest occurrence of Coccolithus miopelagicus in Core 152-918D-37R. This is in contrast to previous studies with estimates for the onset of NADW from $\sim 34 \mathrm{Ma}$ to $12.5 \mathrm{Ma}$ based largely on carbon isotope data from middle to low latitudes (Schnitker, 1980; Blanc et al., 1980; Miller and Fairbanks, 1985; Wright et al., 1992).

The first indication of extensive glaciation on Greenland was identified by the lowest occurrence of dropstones in Core 152-918D28R (Larsen, Saunders, Clift, et al., 1994). Shipboard nannofossil and planktonic foraminiferal biostratigraphy suggested an age of about 7 Ma or older for this core. This age is consistent with the present nannofossil data. The maximum age for Core 152-918D-28R is not well constrained as the next available datum downhole is the last occurrence of Coccolithus mipelagicus (11 Ma) in Core 152-918D-37R. It 
Table 6. Distribution of calcareous nannofossils, Site 919.

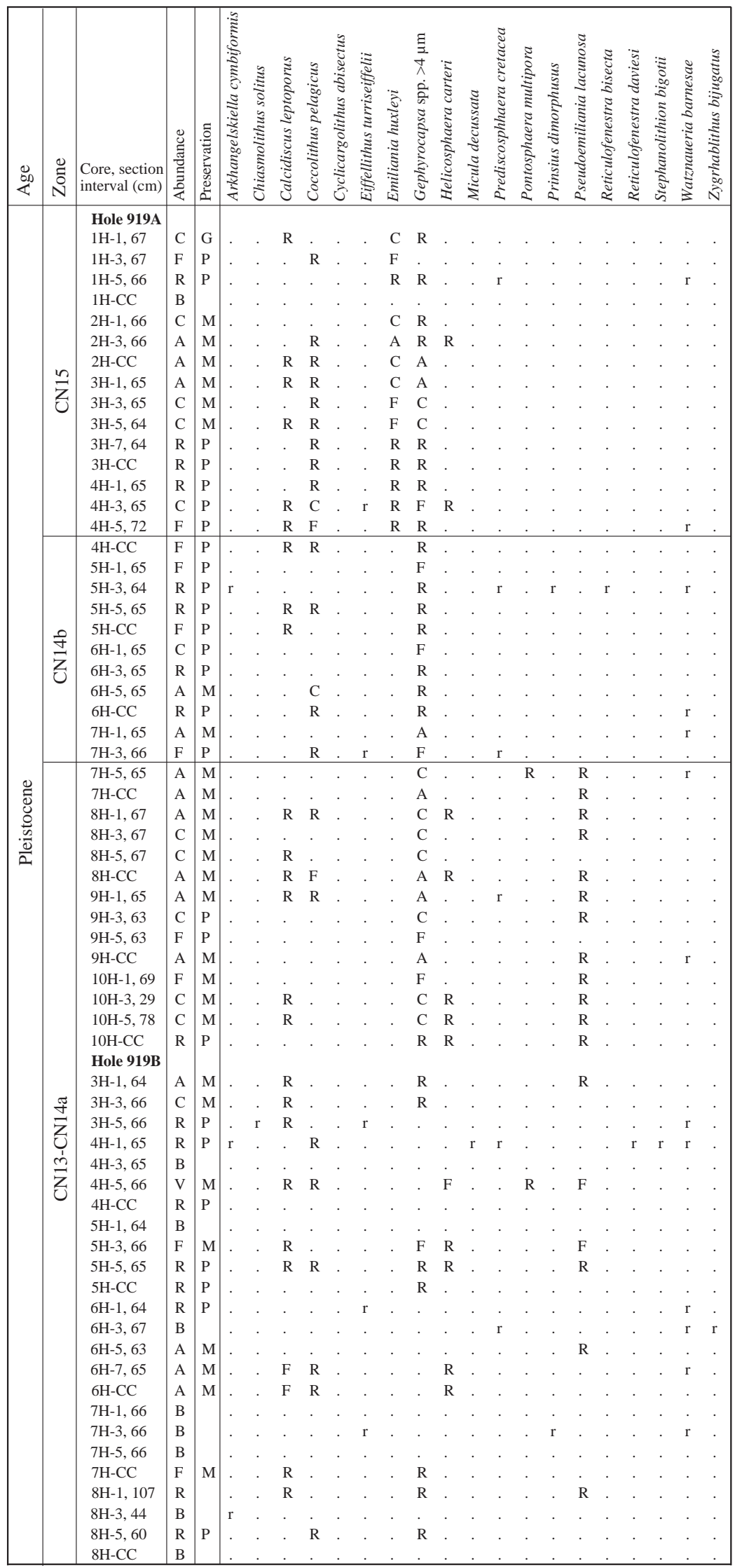

Note: $\mathrm{V}=$ very abundant, $\mathrm{A}=$ abundant, $\mathrm{C}=$ common, $\mathrm{F}=$ few, $\mathrm{R}=$ rare, $\mathrm{B}=$ barren, $\mathrm{M}=$ moderate, and $\mathrm{P}=$ poor. 
is clear though that the ice-rafted detritus from Site 918 represents the oldest Greenland glacial record ever observed.

Cretaceous nannofossils are sporadically present in the Pleistocene sediments (see Table 6) but are absent in older sediments. There was no Cretaceous nannofossil deposition in the Canadian Arctic, Greenland, Greenland-Norwegian Sea, or the Arctic Ocean. The Cretaceous nannofossils most likely were ice-rafted from northwest Europe. Indeed, significantly more Cretaceous nannofossils (up to $100 \%$ of the nannofossil assemblages) have been found in the Pleistocene sediments of Leg 104 sites in the Norwegian Sea, whereas Cretaceous nannofossils are virtually absent in older sediments in these sites (Donnally, 1989; Henrich and Baumann, 1994; Wei, unpubl. data). The reworked nannofossils are most abundant in the glacial/deglacial intervals (Henrich and Baumann, 1994). Furthermore, Cretaceous nannofossils have been found in the Heinrich layers at DSDP Site $609\left(50^{\circ} \mathrm{N} ; 24^{\circ} \mathrm{W}\right)$ in the North Atlantic Ocean (Wei, unpubl. data). The Heinrich layers are generally believed to have been the results of massive discharges of icebergs during colder episodes of glacial periods (Broecker et al., 1992; Bond et al., 1992; Fronval et al., 1995). All of this suggests that the reworked Cretaceous nannofossils were transported by icebergs. Such icebergs most likely originated from the North Sea-Denmark area, where nannofossil-rich chalk facies are present and extensively exposed.

The presence of Cretaceous nannofossils in the Pleistocene $(<0.9$ $\mathrm{Ma})$ and their virtual absence in older sediments both on the East Greenland Margin and in the Norwegian Sea may suggest that extensive discharge of icebergs from the North Sea-Denmark area began in the middle Pleistocene, around 0.9 Ma. This is the time of the so called "Mid-Pleistocene Climate Revolution" (Berger et al., 1993; Berger and Jansen, 1994), when climate changed from prominently 41-k.y. cycles (obliquity-related forcing) to prominently 100-k.y. cycles (eccentricity-related forcing). This change in climate cyclicity could be due to an increase of marine-based ice sheets like the one grounded in the North Sea area. The increased instability of the marine-based ice sheets and the fluctuations of the albedos could amplify the eccentricity forcing, causing the prominently 100-k.y. climate cycles.

\section{SUMMARY}

The distribution of calcareous nannofossils in Leg 152 sites has been documented in range charts, which forms the basis for biostratigraphic interpretations. The nannofossil biostratigraphy provides the primary means of dating the sediments. The commencement of marine sedimentation at Site 918 in the Irminger Basin is dated as the early Eocene (52-53 Ma), shortly ( $<3$ m.y.) after the youngest basalt sequence was formed above sea level (Larsen, Saunders, Clift, et al., 1994). Marine sedimentation at Site 917 on the continental shelf began later, in the middle Eocene ( 40-42 Ma), even though the basalts here were formed earlier than those at Site 918. Nannofossil biostratigraphy reveals a number of hiatuses, including a long one (middle Eocene-late Oligocene) in the Irminger Basin Site 918 that may be caused by strong local tectonic activities.

Nannofossil assemblages of the Eocene are similar to those in the lower latitudes as well as those in the southern high latitudes. This suggests significant warmth in the high latitudes during the Eocene. Species diversity generally decreased through the later part of the Cenozoic, in response to a cooling trend. Discoasters, which are considered as warm water taxa, persisted to the Pliocene at these northern high latitudes, in contrast to southern high latitudes, where discoasters totally disappeared by the late Eocene. The last consistent occurrence of discoasters at about $12 \mathrm{Ma}$ in the Irminger Basin may suggest that the cold East Greenland Current began to flow through the Denmark Strait. Other important events dated by the nannofossil biostratigraphy include the onset of NADW at about $11.5 \mathrm{Ma}$ and the earliest dropstones in the Irminger Basin at about $7 \mathrm{Ma}$ or older.
The stratigraphic distribution of reworked Cretaceous nannofossils in the Irminger Basin is similar to that in the Norwegian Sea and may suggest that extensive discharge of icebergs from the North SeaDenmark area began in the middle Pleistocene, and that the icebergs not only drifted to the Norwegian Sea but also reached the Irminger Basin during glacial periods.

\section{ACKNOWLEDGMENTS}

I thank the crew of the JOIDES Resolution, the ODP technical staff, and the Leg 152 Scientific Party, particularly H. C. Larsen and A. Saunders (Co-Chief Scientists) and P. Clift (Staff Scientist), for making a very successful cruise. I also thank T. Staerker, K. von Salis, and S. Wise for helpful reviews. A. Peleo-Alampay helped prepare the plates. This study was funded by USSAC grants. Additional support was provided by the U.S. National Science Foundation and Petroleum Research Foundation.

\section{REFERENCES}

Berger, W.H., Bickert, T., Schmidt, H., and Wefer, G., 1993. Quaternary oxygen isotope record of pelagic foraminifers: Site 806, Ontong Java Plateau. In Berger, W.H., Kroenke, L.W., Mayer, L.A., et al., Proc. ODP, Sci. Results, 130: College Station, TX (Ocean Drilling Program), 381-395.

Berger, W.H., and Jansen, E., 1994. Mid-Pleistocene climate shift: the Nansen connection. In Johannessen, O.M., Muensch, R.D., and Overland, J.E. (Eds.), The Role of the Polar Oceans in Shaping the Global Environment. Geophys. Monogr., Am. Geophys. Union, 85:295-311.

Blanc, P.-L., Rabussier, D., Vergnaud-Grazzini, C., and Duplessy, J.-C., 1980. North Atlantic deep water formed by the later middle Miocene. Nature, 283:553-555.

Bond, G., Heinrich, H., Broecker, W., Labeyrie, L., McManus, J., Andrews, J., Huon, S., Janitschik, R., Clasen, S., Simet, C., Tedesco, K., Klas, M., Bonani, G., and Ivy, S., 1992. Evidence for massive discharge of icebergs into the North Atlantic ocean during the last glacial period. Nature, 360:245-249.

Broecker, W., Bond, G.C., Klas, M., Clark, E., and McManus, J., 1992. Origin of the northern Atlantic's Heinrich events. Clim. Dyn., 6:265-273.

Cande, S.C., and Kent, D.V., 1992. A new geomagnetic polarity time scale for the Late Cretaceous and Cenozoic. J. Geophys. Res., 97:1391713951.

, 1995. Revised calibration of the geomagnetic polarity timescale for the Late Cretaceous and Cenozoic. J. Geophys. Res., 100:6093-6095.

Donnally, D.M., 1989. Calcareous nannofossils of the Norwegian-Greenland Sea: ODP Leg 104. In Eldholm, O., Thiede, J., Taylor, E., et al., Proc. ODP, Sci. Results, 104: College Station, TX (Ocean Drilling Program), 459-486.

Firth, J.V., 1989. Eocene and Oligocene calcareous nannofossils from the Labrador Sea, ODP Leg 105. In Srivastava, S. P., Arthur, M.A., Clement, B., et al., Proc. ODP, Sci. Results, 105: College Station, TX (Ocean Drilling Program), 263-286.

Fronval, T., Jansen, E., Bloemendal, J., and Johnsen, S., 1995. Oceanic evidence for coherent fluctuations in Fennoscandian and Laurentide ice sheets on millennium timescales. Nature, 374:443-446.

Gard, G., and Backman, J., 1990. Synthesis of arctic and subarctic coccolith biochronology and history of North Atlantic Drift water influx during the last 500,000 years. In Bleil, U., and Thiede, J. (Eds.), The History of the Polar Oceans: Arctic Versus Antarctic: Dordrecht (Kluwer), 499-518.

Gartner, S., 1992. Miocene nannofossil chronology in the North Atlantic, DSDP Site 608. Mar. Micropaleontol., 18:307-331.

Haq, B.U., Hardenbol, J., and Vail, P.R., 1987. Chronology of fluctuating sea levels since the Triassic. Science, 235:1156-1167.

Henrich, R., and Baumann, K.H. 1994. Evolution of the Norwegian Current and the Scandinavian Ice Sheets during the past 2.6 m.y.: evidence from ODP Leg 104 biogenic carbonate and terrigenous records. Palaeogeogr., Palaeoclimatol., Palaeoecol., 108:75-94.

Knüttel, S., Russell, M.D., and Firth, J.V., 1989. Neogene calcareous nannofossils from ODP Leg 105: implications for Pleistocene paleoceanographic trends. In Srivastava. S.P., Arthur, M.A., Clement, B., et al., Proc. ODP, Sci. Results, 105: College Station, TX (Ocean Drilling Program), 245-262. 
Larsen, H.C., Saunders, A.D., Clift, P.D., et al., 1994. Proc. ODP, Init. Repts., 152: College Station, TX (Ocean Drilling Program).

Miller, K.G., and Fairbanks, R.G., 1985. Oligocene to Miocene carbon isotope cycles and abyssal circulation changes. In Sundquist, E.J., and Broecker, W.S. (Eds.), The Carbon Cycle and Atmospheric $\mathrm{CO}_{2}$ : Natural Variations Archean to Present. Geophys. Monogr., Am. Geophys. Union, 32:469-486.

Müller, C., 1976. Tertiary and Quaternary calcareous nannoplankton in the Norwegian-Greenland Sea, DSDP, Leg 38. In Talwani, M., Udintsev, G., et al., Init. Repts. DSDP, 38: Washington (U.S. Govt. Printing Office), 823-841.

Okada, H., and Bukry, D., 1980. Supplementary modification and introduction of code numbers to the low-latitude coccolith biostratigraphic zonation (Bukry, 1973; 1975). Mar. Micropaleontol., 5:321-325.

Perch-Nielsen, K., 1985. Cenozoic calcareous nannofossils. In Bolli, H.M., Saunders, J.B., and Perch-Nielsen, K. (Eds.), Plankton Stratigraphy: Cambridge (Cambridge Univ. Press), 427-554.

Pospichal, J.J., and Wise, S.W., Jr., 1990. Paleocene to middle Eocene calcareous nannofossils of ODP Sites 689 and 690, Maud Rise, Weddell Sea. In Barker, P.F., Kennett, J.P., et al., Proc. ODP. Sci. Results, 113: College Station, TX (Ocean Drilling Program), 613-638.

Schnitker, D., 1980. North Atlantic oceanography as possible cause of Antarctic glaciation and eutrophication. Nature, 284:615-616.

Steinmetz, J.C., 1978. Calcareous nannofossils from the North Atlantic Ocean, Leg 49, Deep Sea Drilling Project. In Luyendyk, B.P., Cann, J.R. et al., Init. Repts. DSDP, 49: Washington (U.S. Govt. Printing Office), 519-531.
Thierstein, H.R., Geitzenauer, K., Molfino, B., and Shackleton, N.J., 1977. Global synchroneity of late Quaternary coccolith datum levels: validation by oxygen isotopes. Geology, 5:400-404.

Wei, W., 1993. Calibration of Upper Pliocene-Lower Pleistocene nannofossil events with oxygen isotope stratigraphy. Paleoceanography, 8:85-99. , 1995. Revised age calibration points for the geomagnetic polarity time scale. Geophys. Res. Lett., 22:957-960.

Wei, W., and Wise, S.W., Jr., 1990. Middle Eocene to Pleistocene calcareous nannofossils recovered by Ocean Drilling Program Leg 113 in the Weddell Sea. In Barker, P.F., Kennett, J.P., et al., Proc. ODP, Sci. Results, 113: College Station, TX (Ocean Drilling Program), 639-666.

, 1992. Eocene-Oligocene calcareous nannofossil magnetobiochronology of the Southern Ocean. Newsl. Stratigr., 26:119-132.

Wright, J.D., Miller, K.G., and Fairbanks, R.G., 1992. Early and middle Miocene stable isotopes: implications for deepwater circulation and climate. Paleoceanography, 7:357-389.

Young, J.R., Flores, J.-A., and Wei, W., 1994. A summary chart of Neogene nannofossil magnetobiostratigraphy. J. Nannoplankton Res., 16:21-27.

Date of initial receipt: 12 June 1995

Date of acceptance: 13 April 1996

Ms 152SR-215 

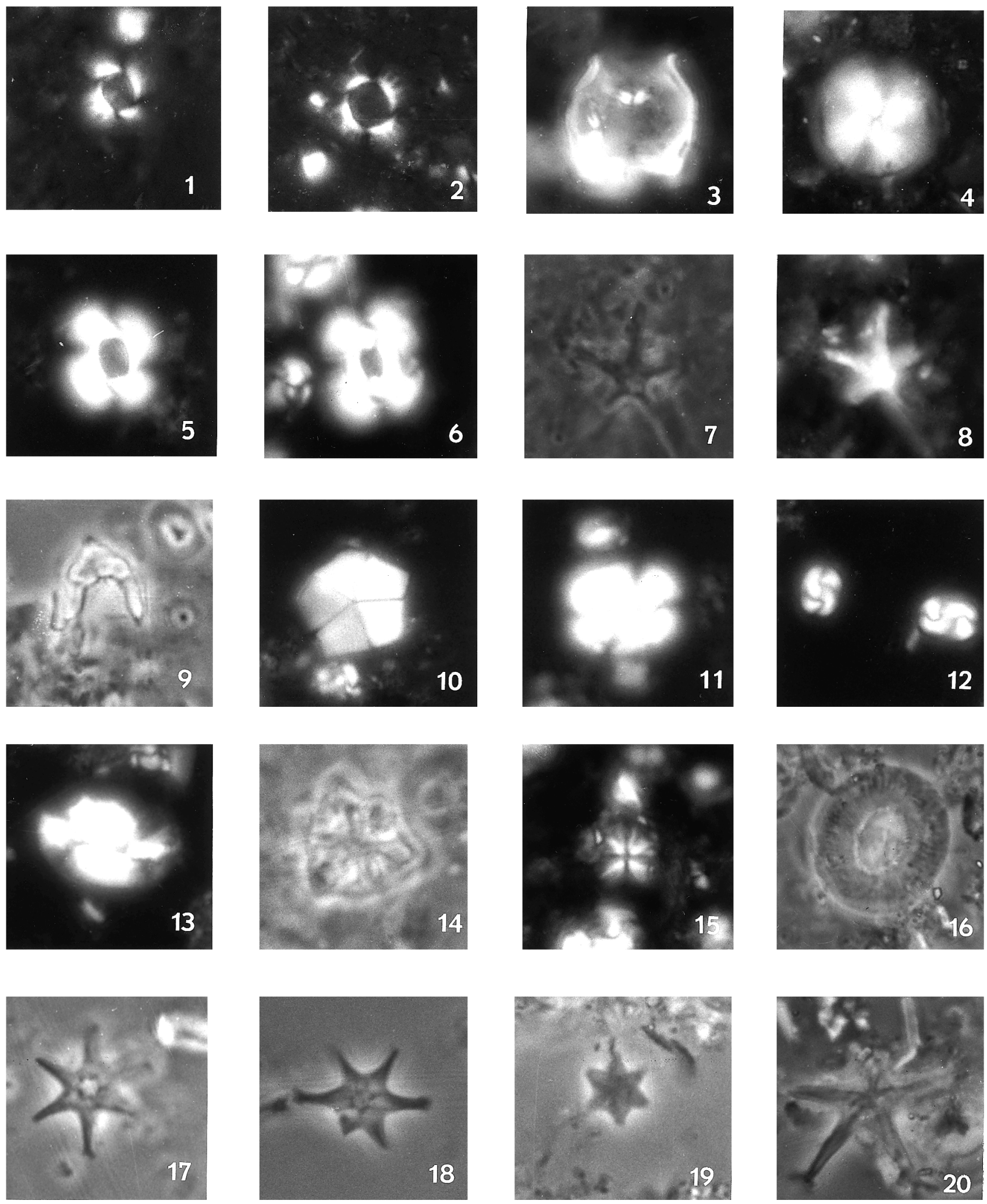

Plate 1. 1, 2. Pseudoemiliania lacunosa, 2000×, Sample 152-919A-7H-5, 65 cm. 3. Scyphosphaera sp., 2000×, Sample 152-919A-8H-1, 67 cm. 4. Calcidiscus leptoporus, 2700×, Sample 152-919B-6H-CC. 5, 6. Reticulofenestra gelida, 2700×, Sample 152-918D-14R-1, 109 cm. 7, 8. Discoaster quinqueramus, 2700×, Sample 152-918D-24R-3, 49 cm. 9. Amaurolithus delicatus? 2700×, Sample 152-918D-24R-CC. 10. Braarudosphaera bigelowii, 2700×, Sample 152-918D-36R-CC. 11. Reticulofenestra perplexa, 2700×, Sample 152-918D-36R-CC. 12. Reticulofenestra producta, 2700×, Sample 152-918D-36R-CC. 13. Helicosphaera carteri, 2700×, Sample 152-918D-36R-CC. 14. Lithostramation perdurum, 2700×, Sample 152-918D-36R-CC. 15. Sphenolithus moriformis, $2700 \times$, Sample 152-918D-36R-CC. 16. Coccolithus miopelagicus, $1500 \times$, Sample 152-918D-38R-4, $54 \mathrm{~cm}$. 17, 18. Discoaster intercalaris, 2700×, Sample 152-918D-38R-2, 61 cm. 19. Discoaster sp. 1, 2700×, Sample 152-918D-37R-5, 93 cm. 20. Discoaster sp. 2, 2700×, Sample 152-918D-39R-3, $93 \mathrm{~cm}$. 

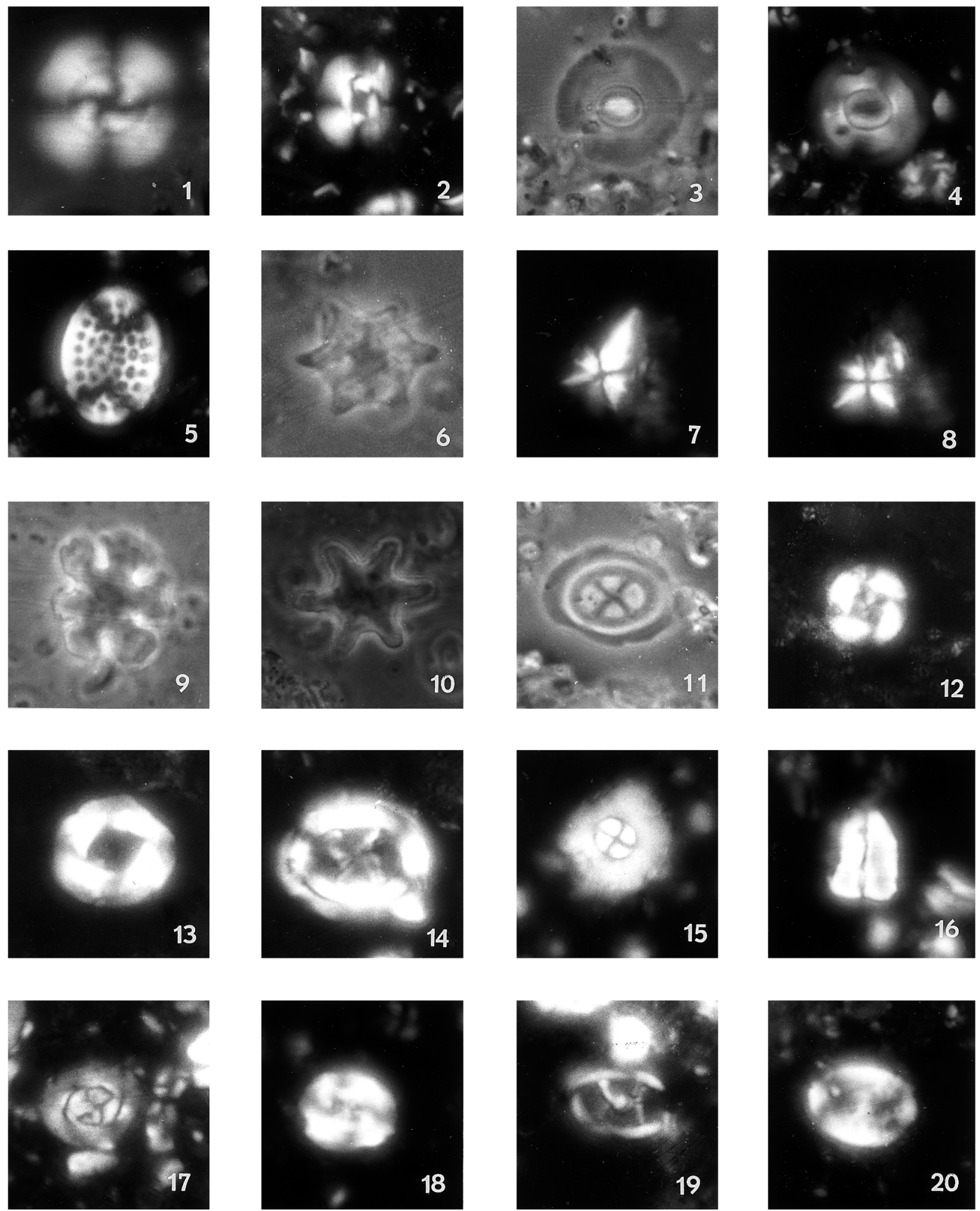

Plate 2. 1. Cyclicargolithus abisectus, 2300×, Sample 152-918D-39R-2, 95 cm. 2. Cycllicargolithus floridanus, 2300×, Sample 152-918D-39R-5, $80 \mathrm{~cm} .3$ 3. 4alcidiscus premacintyrei, 2300×, Sample 152-918D-39R-4, $18 \mathrm{~cm}$. 5. Pontosphaera multipora, 2300×, Sample 152-918D-39R-4, $18 \mathrm{~cm}$. 6. ?Catinaster sp., 2300×, Sample 152-918D-43R-2, $52 \mathrm{~cm}$. 7, 8. Sphenolithus heteromorphus, 2300×, Sample 152-918D-43R-1, $72 \mathrm{~cm} .9$. Discoaster sp. 3., 2300×, Sample 152-918D-54R-CC. 10. Discoaster druggii? 1500×, Sample 152-918D-24R-CC. 11. Chiasmolithus altus, 2000×, Sample 152-918D-75R-1, $56 \mathrm{~cm}$. 12. Reticulofenestra reticulata, 2300×, Sample 152-918D-88R-1, $2 \mathrm{~cm}$. 13. Reticulofenestra samodurovii, 2300×, Sample 152-918D-88R-1, 2 cm. 14. Chiasmolithus solitus, 2300×, Sample 152-918D-88R-1, 2 cm. 15. Markalius inversus, 2700×, Sample 152-918D-88R-CC. 16. Zygrhablithus bijugatus, 2300×, Sample 152-918D-88R-CC. 17. Clausicoccus fenestratus, 2700×, Sample 152-918D-88R-CC. 18. Reticulofenestra daviesii, 2700×, Sample 152-918D-88R-CC. 19. Neococcolithes dubius, 2700×, Sample 152-918D89R-CC. 20. Transversopontis pulcher, 2700×, Sample 152-918D-89R-CC. 

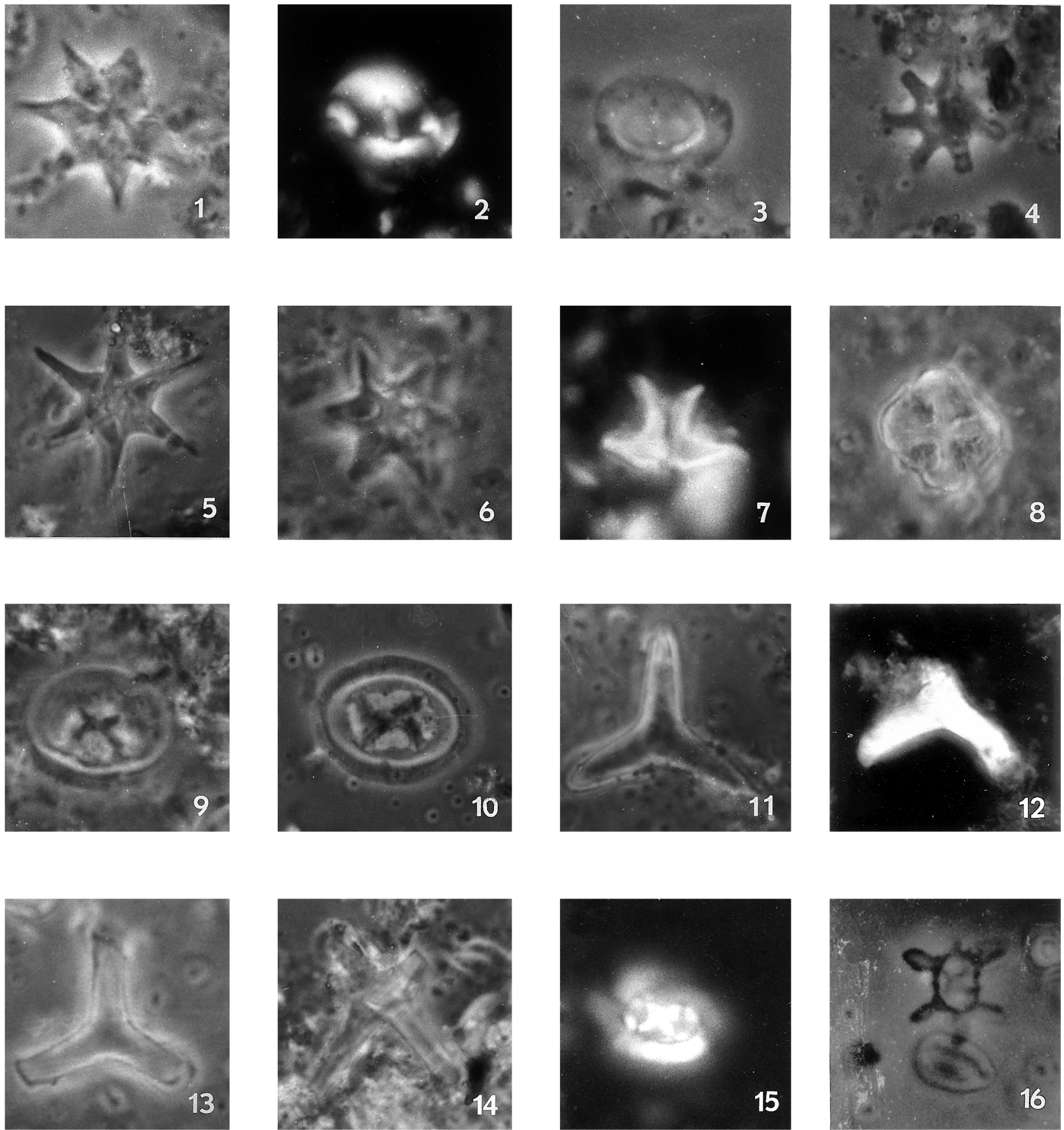

Plate 3. 1. Discoaster saipanensis, 2300×, Sample 152-915A-15R-CC. 2, 3. Helicosphaera seminulum, 2300×, Sample 152-918D-89R-CC. 4. Discoaster sp. 4, 2300×, Sample 152-918D-89R-CC. 5, 6. Discoaster lodoensis, 1500×, Sample 152-918D-90R-CC. 7. Discoaster kuepperi, 2300×, Sample 152-918D-90R-2, 39 cm. 8. Nannotetrina cristata, 2300×, Sample 152-918D-88R-CC. 9. Chiasmolithus expansus, 2000×, Sample 152918D-90R-3, 39 cm. 10. Chiasmolithus eograndis, 2000x, Sample 152-918D-93R-CC. 11, 12, 13. Tribrachiatus orthostylus, 1500x. (11, 12) Sample 152-92R-1, 57 cm, and (13) Sample 152-918D-93R-CC. 14. Imperiaster obscurus, 1500×, Sample 152-918D-93R-CC. 15. Prediscosphaera cretacea (reworked Cretaceous species), 2300×, Sample 152-919B-6H-3, $67 \mathrm{~cm}$. 16. Stephanolithion bigotii (the only reworked Jurassic species observed in this study), 2300×, Sample 152-919B-4H-1, $65 \mathrm{~cm}$. 